\title{
Discovery of an unknown diversity of Leucinodes species damaging Solanaceae fruits in sub-Saharan Africa and moving in trade (Insecta, Lepidoptera, Pyraloidea)
}

\author{
Richard Mally', Anastasia Korycinska², David J. L. Agassiz ${ }^{3}$, \\ Jayne Hall2, Jennifer Hodgetts ${ }^{2}$, Matthias Nuss ${ }^{4}$
}

I University Museum of Bergen, Realfagbygget, Allégaten 41, 5007 Bergen, Norway 2 The Food and Environment Research Agency, Sand Hutton, York, YO41 1LZ, United Kingdom 3 The Natural History Museum, London SW7 5BD, United Kingdom 4 Senckenberg Natural History Collections Dresden, Königsbrücker Landstr. 159, 01109 Dresden, Germany

Corresponding author: Richard Mally (richard.mally@um.uib.no)

Academic editor: Colin Plant | Received 20 October 2014 | Accepted 3 December 2014 | Published 19 January 2015

http://zoobank.org/F9D10185-A581-4240-93C1-B35A960F5F88

Citation: Mally R, Korycinska A, Agassiz DJL, Hall J, Hodgetts J, Nuss M (2015) Discovery of an unknown diversity of Leucinodes species damaging Solanaceae fruits in sub-Saharan Africa and moving in trade (Insecta, Lepidoptera, Pyraloidea). ZooKeys 472: 117-162. doi: 10.3897/zookeys.472.8781

\begin{abstract}
The larvae of the Old World genera Leucinodes Guenée, 1854 and Sceliodes Guenée, 1854 are internal feeders in the fruits of Solanaceae, causing economic damage to cultivated plants like Solanum melongena and S. aethiopicum. In sub-Saharan Africa five nominal species of Leucinodes and one of Sceliodes occur. One of these species, the eggplant fruit and shoot borer L. orbonalis Guenée, 1854, is regarded as regularly intercepted from Africa and Asia in Europe, North and South America and is therefore a quarantine pest on these continents. We investigate the taxonomy of African Leucinodes and Sceliodes based on morphological characters in wing pattern, genitalia and larvae, as well as mitochondrial DNA, providing these data for identification of all life stages. The results suggest that both genera are congeneric, with Sceliodes syn. n. established as junior subjective synonym of Leucinodes. L. orbonalis is described from Asia and none of the samples investigated from Africa belong to this species. Instead, sub-Saharan Africa harbours a complex of eight endemic Leucinodes species. Among the former nominal species of Leucinodes (and Sceliodes) from Africa, only L. laisalis (Walker, 1859), comb. n. (Sceliodes) is confirmed, with Leucinodes translucidalis Gaede, 1917, syn. n. as a junior subjective synonym. The other African Leucinodes species were unknown to science and are described as new: L. africensis sp. n., L. ethiopica sp. n., L. kenyensis sp. n., L. malawiensis sp. n., L. pseudorbonalis sp. n., L. rimavallis sp. n. and L. ugandensis sp. n. An identification key based on male genitalia is provided for the African Leucinodes species. Most imports
\end{abstract}

Copyright Richard Mally et al. This is an open access article distributed under the terms of the Creative Commons Attribution License (CC BY 4.0), which permits unrestricted use, distribution, and reproduction in any medium, provided the original author and source are credited. 
of Leucinodes specimens from Africa into Europe refer to Leucinodes africensis, which has been frequently imported with fruits during the last 50 years. In contrast, L. laisalis has been much less frequently recorded, and $L$. pseudorbonalis as well as $L$. rimavallis only very recently in fruit imports from Uganda. Accordingly, interceptions of Leucinodes from Africa into other continents will need to be re-investigated for their species identity and will likely require, at least in parts, revisions of the quarantine regulations. The following African taxa are excluded from Leucinodes: Hyperanalyta Strand, 1918, syn. rev. as revised synonym of Analyta Lederer, 1863; Analyta apicalis (Hampson, 1896), comb. n. (Leucinodes); Lygropia aureomarginalis (Gaede, 1916), comb. n. (Leucinodes); Syllepte hemichionalis Mabille, 1900, comb. rev., S. hemichionalis idalis Viette, 1958, comb. rev. and S. vagans (Tutt, 1890), comb. n. (Aphytoceros). Deanolis iriocapna (Meyrick, 1938), comb. n. from Indonesia is originally described and misplaced in Sceliodes, and L. cordalis (Doubleday, 1843), comb. n. (Margaritia) from New Zealand, L. raondry (Viette, 1981) comb. n. (Daraba) from Madagascar as well as L. grisealis (Kenrick, 1912), comb. n. (Sceliodes) from New Guinea are transferred from Sceliodes to Leucinodes. While Leucinodes is now revised from Africa, it still needs further revision in Asia.

\section{Keywords}

Leucinodes, Leucinodes orbonalis complex, Sceliodes, Solanaceae, eggplant, pest species, DNA Barcoding, revision, identification key, Africa

\section{Introduction}

Leucinodes orbonalis Guenée, 1854, the eggplant fruit and shoot borer, is a species of moth that was first described from specimens from India and Java (Guenée 1854). According to current knowledge, it is widely distributed in tropical and subtropical Asia (CABI 2012a) and sub-Saharan Africa (Walker 1859, Frempong 1979, CABI 2012a). The larvae are pests of Solanaceae, especially Solanum melongena L. (aubergine, eggplant or brinjal) fruits and stems where they feed internally. Their infestation can substantially reduce yields from aubergine cultivation, and yield losses of more than 65\% have been recorded from Asia (EPPO 2008).

The larvae are commonly moved in international trade with plants and fruits, as their internal feeding and the resulting damage may not be visible during pre-export inspections. Thus, Leucinodes orbonalis is a quarantine pest of concern to a number of countries outside its native range. This includes the member countries of the European and Mediterranean Plant Protection Organisation (EPPO), where it was recommended as an addition to the alert list of pests in 2008 (EPPO 2008), and in 2012 transferred to the A1 list of pests recommended for statutory regulation (EPPO 2012, 2013). It is an A1 pest for several South American countries including Uruguay and Argentina (COSAVE 2006) and has repeatedly been intercepted in the USA (Whittle and Ferguson 1987, Solis 1999, 2006). In England and Wales, the Plant Health and Seeds Inspectorate (PHSI) regularly intercept Leucinodes Guenée, 1854 larvae inside aubergines from South Asia and West Africa (The Food and Environment Research Agency (Fera), unpublished data).

Due to the economic impact of Leucinodes orbonalis, the development of a genetically modified eggplant was initiated in 2005 in India by introducing a crystal protein 
gene (Cry1Ac) from the bacterium Bacillus thuringiensis Berliner, $1915(B t)$ into the plant (Sood 2012). The insecticidal effect of the crystal proteins makes eggplant less susceptible to infestations by larvae of Leucinodes orbonalis. After field trials and approval for commercial cultivation from government scientists in 2009, a moratorium on the commercialisation of $B t$ brinjal was imposed due to public concerns on food safety (Pandey 2010).

Until recently, all pyraloid larvae damaging Solanaceae fruits in Asia and Africa and intercepted from imports to Europe have been regarded as two species, Leucinodes orbonalis and Sceliodes laisalis (Walker, 1859). Hayden et al. (2013) and Gilligan and Passoa (2014) pointed out that Leucinodes orbonalis is restricted to Asia and that there are "three species in the L. orbonalis complex in Africa that are not conspecific with the Asian species. Our investigations reveal that an even largernumber of Leucinodes species are intercepted from Africa. This points to the question of the identity of the intercepted species as well as on further four species of Leucinodes known from Africa, L. aureomarginalis Gaede, 1916, L. hemichionalis (Mabille, 1900), L. translucidalis Gaede, 1917 and L. vagans (Tutt, 1890) (Nuss et al. 2003-2014). Besides Leucinodes, there is the similar genus Sceliodes Guenée, 1854, of which Sceliodes cordalis (Doubleday, 1843) and S. laisalis (Walker, 1859) are also pests on solanaceous crops in Australia (Davis 1964), New Zealand (Martin 2010) and Africa (CABI 2012b).

Here we taxonomically revise Leucinodes and Sceliodes and their species from continental sub-Saharan Africa, in order to delimit species and to allow their proper identification.

\section{Methods}

Specimens were examined from the following institutions: private collection David J. L. Agassiz, Weston-super-Mare, Great Britain (coll. DJLA), Natural History Museum, London, Great Britain (BMNH), Invertebrate Reference Collection, Food and Environment Research Agency, Sand Hutton, England (Fera), International Centre of Insect Physiology and Ecology, Nairobi, Kenya (ICIPE), private collection Timm Karisch, Dessau, Germany (coll. Karisch), University of Oslo, Natural History Museum, Norway (NHMO), National Museum of Kenya, Nairobi, Kenya (NMK), National Plant Protection Organization, Wageningen, the Netherlands (NPPO), Muséum national d'Histoire naturelle, Paris, France (MNHN), Musée royal de l'Afrique centrale, Tervuren, Belgium (RMCA), Senckenberg Deutsches Entomologisches Institut, Müncheberg, Germany (SDEI), Senckenberg Museum für Tierkunde, Dresden, Germany (SMTD), National Museum of Natural History, Washington, D.C., U.S.A. (USNM), Museum für Naturkunde, Berlin, Germany (ZMHB), University of Copenhagen, Museum of Zoology, Denmark (ZMUC).

Larvae were sourced through quarantine interceptions of eggplant fruit from Africa and Asia at several ports of entry in England. Most larvae were studied alive and subsequently reared to adults in order to confirm the species identity. In large containments a few larvae were preserved by boiling them in water for 30-90 seconds, then transferred to $70 \%$ ethanol. After 3-5 days, the ethanol was replaced to limit dilution from body contents. Reared adults were killed soon after emergence, with cyanide, ammonia or by 
freezing at $-20{ }^{\circ} \mathrm{C}$ for a minimum of 2 hours. Field-collected adults were attracted by artificial light and killed with cyanide. All adult specimens were subsequently pinned. Genital dissections of thoroughly dried specimens were performed according to Robinson (1976). Setal nomenclature follows Hinton (1946). The chaetotaxic descriptions and the setal map focus on those microscopic setae visible at $60 \times$ magnification.

DNA was extracted using either the NucleoSpin tissue kit (Macherey-Nagel) according to the manufacturer's instructions or using the Chelex-100 resin based method (Boonham et al. 2002). DNA extraction with the NucleoSpin tissue kit was performed following the procedure of Knölke et al. (2005), extracting DNA from the abdomen of adult specimens and subsequent dissection of the genitalia from the macerated abdomen. Extracted abdomina were stored in $70 \%$ ethanol until genitalia were dissected. For the Chelex-100 resin based method single legs or wings were removed from dried, pinned specimens using fine forceps and placed in individual $0.6 \mathrm{ml}$ Eppendorf tubes. Briefly, $100 \mu \mathrm{l}$ moleculargrade water was added to the tissue sample and ground using a micropestle. $100 \mu \mathrm{l}$ of a $50 \% \mathrm{w} / \mathrm{v}$ chelex resin:water slurry was added, the sample heated to $95^{\circ} \mathrm{C}$ for 5 minutes, centrifuged for 5 minutes and the supernatant transferred and stored at $-20^{\circ} \mathrm{C}$ prior to use.

PCR of the $5^{\prime}$ half of the cytochrome $\mathrm{C}$ oxidase subunit I (COI) gene, the socalled DNA Barcode (for Metazoa), was performed using primers HybLCO (Folmer et al. 1994, Wahlberg and Wheat 2008) and HybNancy (Wahlberg and Wheat 2008). For degraded material primer pairs HybLCO/K699 and Ron/HybNancy (Wahlberg and Wheat 2008) were used to amplify the COI Barcode in two fragments. PCR was performed in $25 \mu \mathrm{l}$ reactions comprising $0.4 \mathrm{u}$ BIO-X-ACT Short DNA Polymerase (Bioline), $2.5 \mu \mathrm{l} 10 \times$ OptiBuffer, $1.5 \mathrm{mM} \mathrm{MgCl}_{2}, 200 \mathrm{nM}$ each primer, $200 \mathrm{nM}$ dNTP mix and 1-2 $\mu \mathrm{DNA}$ (concentration as extracted). Cycling conditions were as follows: initial denaturation for $5 \mathrm{~min}$ at $95^{\circ} \mathrm{C}, 40$ cycles with 1) $30 \mathrm{sec}$ at $95^{\circ} \mathrm{C}$, 2) $30 \mathrm{sec}$ at $48^{\circ} \mathrm{C}$, 3) $90 \mathrm{sec}$ (HybLCO/HybNancy) or $60 \mathrm{sec}$ (primers for degraded material) at $70{ }^{\circ} \mathrm{C}$, final extension of $10 \mathrm{~min}$ at $70^{\circ} \mathrm{C}$. Alternatively primers LepF and LepR (Hajibabaei et al. 2006) were used in $25 \mu \mathrm{l}$ PCR reactions using BIO-X-ACT Short $2 \times$ mix (Bioline), $400 \mathrm{nM}$ each primer and 1-2 $\mu \mathrm{l}$ DNA (concentration as extracted). Cycling conditions were as follows: initial denaturation for $5 \mathrm{~min}$ at $94^{\circ} \mathrm{C}, 35$ cycles with 1) $30 \mathrm{sec}$ at $\left.94^{\circ} \mathrm{C}, 2\right) 45 \mathrm{sec}$ at $\left.50^{\circ} \mathrm{C}, 3\right) 1 \mathrm{~min}$ at $72^{\circ} \mathrm{C}$, final extension of $10 \mathrm{~min}$ at $72^{\circ} \mathrm{C}$.

PCR products were visualised by separation in $1-1.5 \%$ agarose gels in $1 \times \mathrm{TBE}$ buffer ( $89 \mathrm{mM}$ Tris-borate $2 \mathrm{mM}$ EDTA) containing GelRed or ethidium bromide and visualised under UV light. PCR amplicons were cleaned up using ExoSAP-IT (Affymetrix) or QIAquick PCR purification kit (QIAGEN). Sequencing of both strands was performed by Eurofins MWG Operon (Germany) or in-house as follows. Sequencing PCRs were performed with BigDye Terminator v3.1 cycle sequencing kit (Applied Biosystems) using 5pm of the sequencing primer tails T7/T3 (Wahlberg and Wheat 2008) and 0.5-4 $\mu$ PCR product. Final clean-up was done via sodium acetate-ethanol precipitation. Sequencing was performed on a 3130 Genetic Analyzer (Applied Biosystems). PCRs, PCR clean-up and sequencing PCRs were performed on a Mastercycler ep gradient S (Eppendorf) or GeneAmp9700 (Applied Biosystems).

Obtained DNA sequences were proofread by eye and aligned using PhyDE 0.9971 (Müller et al. 2008) or MEGA version 4.1 (Tamura et al. 2007). Ambiguous 
Barcode nucleotides were coded according to the IUPAC Ambiguity Code (CornishBowden 1985). Sequences were then checked for plausibility using BLAST with the blastn algorithm (Altschul et al. 1990; URL: http://blast.ncbi.nlm.nih.gov/Blast.cgi) as well as the BOLD Identification System (IDS, URL: http://www.boldsystems.org/ index.php/IDS_OpenIdEngine). A 615 basepair fragment was analyzed with MEGA version 6 (Tamura et al. 2013), using the distance criterion and the Neighbor Joining (NJ) algorithm (Saitou and Nei 1987) with uncorrected p-distances (Srivathsan and Meier 2011). Statistical support was evaluated through 1,000 Bootstrap replicates. Udea ferrugalis (Hübner, 1796) was used to root the NJ tree.

We apply the morphospecies concept to our study. The DNA Barcode is used as additional source of information and as an identification tool for all developmental stages of African Leucinodes species. The Solanaceae species names mentioned in this study refer to their former context and do not necessarily correspond to the revised Solanum taxonomy by Knapp et al. (2013).

Label data of studied specimens were compiled in order to generate a distribution map. Geographical coordinates, if not given on the label, were obtained via Google Earth, Version 5.2.1.1588 and subsequently plotted on a map using DIVA-GIS, Version 7.2.3 (Hijmans et al. 2004).

\section{Data resources}

The data underpinning the analyses reported in this paper are deposited in the Dryad Data Repository at doi: 10.5061/dryad.kk0n9.

\section{Results}

\section{Leucinodes Guenée, 1854}

Leucinodes Guenée, 1854. Type species: Leucinodes orbonalis Guenée, 1854

= Sceliodes Guenée, 1854, syn. n. Type species: Sceliodes mucidalis Guenée, 1854

= Daraba Walker, 1859 (synonymised by Hampson, 1899). Type species: Daraba idmonealis Walker, 1859

= Eretria Snellen, 1880 (synonymised by Hampson, 1899; Shaffer et al. 1996: junior homonym of Eretria Robineau-Desvoidy, 1863). Type species: Eretria obsistalis Snellen, 1880

= Leuctinodes South, 1897 (misspell.)

Diagnosis. Leucinodes is characterized by a forewing pattern which includes a brown base, a white antemedian line which is distally brown edged; a median area that is ochreous or brown from the costa to the middle of wing, and red-brown from the middle of wing towards the dorsum; below the apex is a black-brown half moon-shaped patch (missing in L. malawiensis sp. n.), edged by a thin white postmedian line and a 
white line at the margin of wing. The hindwings are white with inconspicuous pattern elements. Leucinodes females with only one frenular bristle in the hindwing, female labial palps with elongated $3^{\text {rd }}$ meron, male genitalia with identical location of the fibula-sacculus process-complex (process lacking in L. cordalis (Doubleday, 1843), L. laisalis and $L$. malawiensis), female genitalia with fine granular sclerotization of ductus bursae (in most species), antrum with thickened mesocuticula, presence of lateral antrum pockets. Larvae are internal feeders in Solanaceae.

Redescription of adults. Head. Frons conically bulged (Figs 11-12) to flat; labial palps porrect, brownish, $1^{\text {st }}$ meron on ventral side with forward-directed tuft, 3 rd meron in males half as long as $2^{\text {nd }}$ meron, longer in females (Figs 11-12); maxillary palps minute or missing; haustellum well developed; eyes large, hemispherical; ocelli present; antennae ciliate, pedicel white to brown, flagellum light brown, cilia in males longer than basal antennal radius (except in L. malawiensis), in females shorter than antennal radius; vertex with whitish to brown scales at the collar and brown scales directed forward; chaetosemata absent.

Thorax. Dorsal side whitish to brown with whitish and dark brown scales mixed in; ventral side whitish; legs predominantly whitish, foreleg femur, tibia and epiphysis light to dark brown; tibial spurs 0,2 , 4 (fore-, mid-, hindleg) with outer spur $1 / 2$ to $2 / 3$ the length of inner spur.

Wings. Forewing white translucent, light brown or orange- to grey-brown, basal area light to dark brown, delimited by white and dark brown double line or in species with brown forewing ground colour by dark brown antemedian line; median area with pale to dark brown, sometimes very faint proximal discoidal stigma (absent in L. malawiensis); distal discoidal stigma pale to dark brown, reaching from costa to forewing centre; central dorsum with prominent orange to dark brown, broadly L-shaped or triangular spot connected or disconnected with distal discoidal stigma; postmedian line sinuate, faint and grey to grey-brown, white edged, with prominent subcostal bulge; apex brown to grey-brown coloured (absent in L. malawiensis), with slim strip of white at outer margin; margin dotted at veins, with large dots at apex and $M_{3}$; fringe white to pale brown with dark interruption at apex and at $\mathrm{M}_{3}$ (absent in L. malawiensis). Hindwing in both sexes with one frenular bristle, ground colour whitish, middle of wing with one or two spots, often faint; postmedian line inconspicuous, bent towards spot at middle of wing; area below apex suffused by pale brown to grey; margin dotted at end of veins, with large dot at end of $\mathrm{M}_{3}$.

Abdomen. First segment whitish, remainder light-, orange- or dark brown to grey.

Male genitalia. Uncus neck constricted, head circular, with dorsal agglomeration of thick setae; narrow transtilla arms with central notch, in L. ethiopica with dorsad spike on each arm; vinculum saccus round to V-shaped, short to more or less elongated, with or without keeled tip; juxta oval, subulate, short rhombical or tongueshaped, with semicircular base; valvae elongate triangular, tapering posteriorly, costa and posterioventral margin loosely covered with long setae; fibula ( $f$ in Fig. 13) arising at central part of mesal wall of valva or near costa; sacculus ( $s a$ in Fig. 13) large, elongate oval, with distal sclerotized process ( $s p$ in Fig. 13), often in close association with fibula, process absent in L. laisalis, L. malawiensis; ventral margin of distal valvae 
with or without granulated area ( $g a$ in Fig. 13); phallus simple, with variously shaped sclerites at posterior apodeme, vesica with or without cornuti.

Female genitalia. Corpus bursae ovoid, membranous, without signa; ductus bursae membranous with delicate granulation, partly reaching into posterior corpus bursae; antrum short to long, slim to broader than ductus bursae, anterior part sometimes coiled, mesocuticula thickened (strongly stained with Chlorazol Black) and exocuticula (inner layer) partly sclerotized; ostium bursae with lateral membranous pockets, with or without oval sclerites; both apophyses pairs simple, apophyses anteriores normally stronger developed than posterior apophyses, with or without broadened central portion.

Immature stages. Larva. Last instar larvae with pink dorsal integument, intersegmental areas cream or light pink, the ventral integument cream; strength of the colouration very variable, pink colour on majority of abdominal segments often interrupted laterally by a transverse cream line; head, prothoracic and anal shields mid brown with variable black markings; early instar larvae white or cream with brown pinacula and black head, prothoracic and anal shields. In older larvae the dorsal integument turns beige, then increasingly deeper pink as the moults progress, head and prothoracic shield brown; pinacula pale brown and prominent against the integument in all instars. The chaetotaxy of the thorax and first nine abdominal segments of the last instar is illustrated in Fig. 35. The relative size of pinacula and positions of setae are very variable intraspecifically. The head is mid to light brown, with variable black markings around ocelli and at genal angle; relative positions of cranial setae very unstable in the specimens examined. The prothoracic shield is light to dark brown with pale median sulcus and two variable dark markings: one along part of the posterior margin, strongest medially, and the other mediolaterally; usually additional darker spots bordering the median sulcus and extending laterally, spots very variable in extent and position; prothoracic L pinaculum crescent shaped with variable posterior extension, L setae anterior to the spiracle, usually vertically aligned; microscopic seta MV3 clearly visible in most specimens, can be almost as prominent as the V seta; MV3 setae share a mid-ventral pinaculum or are on separate pinacula; meso- and metathorax with clearly visible dorsal and subdorsal microscopic pinacula at $60 \times$ magnification; three ventral microscopic setae less prominent, with MV3 usually being the least evident, these with or without small pinacula. Many larvae are asymmetrical in this feature, with a pinaculum on one side, and seta only on the other. On the abdomen, there is one SV seta on segment 1 , three SV setae on a single pinaculum on segment 2; microscopic seta MV3 visible on both segments 1 and 2, not prominent; microscopic setae on segments 3-8 mostly not visible at $60 \times$ magnification; prolegs with crochets in a mesopenellipse; anal shield often lighter brown than pinacula, usually darker pigmented in anterior half.

Pupa. (Figs 42-46) Yellow to pale brown, lightly sclerotized, developing adult clearly visible as development proceeds; two distinct, raised hood-like structures dorsal to spiracles on abdominal segments 2 and 3 (Figs 42, 44); four pairs of long hooked setae ventral to cremaster; cocoon stout leathery, made of silk, firmly attached to the substrate.

Remarks. Sceliodes and Leucinodes have traditionally been distinguished by their forewing ground colour, which is predominantly orange-brown to greyish-brown in Sceliodes and white translucent in Leucinodes. The newly discovered Leucinodes ethi- 
opica sp. n. is intermediate in this character whereas all other wing pattern elements are homologous among Leucinodes and Sceliodes species. Study of the genitalia showed that cornuti are present in Sceliodes species, but are absent in Leucinodes, including L. ethiopica. The female genitalia contain oval to semicircular sclerites in the lateral antrum pockets of L. ethiopica, African Sceliodes and S. cordalis, the type-species of Sceliodes, which is distributed in Australia and New Zealand. Thus, there is a continuous variation between Leucinodes and Sceliodes and we here synonymise Sceliodes syn. n. with Leucinodes. As Leucinodes and Sceliodes have been published on the same date and in the same work, we here give precedence to Leucinodes as it is the better known of the two names, acting as first reviser according to ICZN 24.2.2.

\section{Leucinodes orbonalis Guenée, 1854}

Figs 1, 11-13, 23, 31, 35-37

Leucinodes orbonalis Guenée, 1854: 223.

Type-localities. Bangladesh, Sylhet (male syntype); Java (female syntype).

Material examined. Type-specimens. Syntype $\partial$ [rectangular whitish label with red border, red letters] "Typicum | Specimen", [rectangular whitish label with black border] "Ex. Musaeo | Ach.Guénée", [rectangular beige label] "Paravicini Coll. | B.M. 1937-383.", [rectangular brownish label] "Orbonalis | Gn. Silhet", [rectangular pale yellow label] "Leucinodes Gn. | orbonalis Gn. | Type đิ 756.3.”, [square white label in red letters, slide number and gender in black] "Pyralidae | Brit.Mus. | Slide No. | 4496 " letters] "Typicum | Specimen", [rectangular whitish label with black border] "Ex. Musaeo | Ach.Guénée”, [rectangular white label] "Paravicini Coll. | B.M. 1937-383.", [rectangular pale yellow label] "Leucinodes Gn. | orbonalis Gn. | Type $q$ 756.3.”, transparent capsule with abdomen and left hindwing (BMNH). - Additional material. VIETNAM. $1 \widehat{\delta}^{\Uparrow}$ Lao Cai Province, surrounding of Mt. Fan Si Pan, Nui Se, 1927m, 22²1.168'N 10346.477'E, 20./21.x.2001, leg. S. Löffler, prep. RM503, DNA Barcode BC MTD 01185 (SMTD); SINGAPORE. 101 1 9 leg. H.N. Ridley, BMNH Pyralidae slides No. 23092 \& No. 23100 (BMNH); THE NETHERLANDS (IMPORT). $1{ }^{\Uparrow}$ Amsterdam (Schiphol), import Thailand, 22.xi.2006, ex larva 26.xi.2006, ex pupa 6.xii.2006, leg. S. Roes, det. M v. d. Straten, prep. RM641; 1 + Amsterdam (Schiphol), import Thailand, 8.ii.2005, ex larva, leg. R. Hulzinga, det. M v. d. Straten, prep. RM642 (NPPO); GREAT BRITAIN (IMPORT). see Suppl. material 2 (Fera material).

Diagnosis. Wing pattern indistinguishable from those of $L$. africensis sp. n., L. rimavallis sp. n., L. pseudorbonalis sp. n., L. kenyensis sp. n. and "Leucinodes spp.", but distinguished from $L$. malawiensis by the absence of the forewing basal transversal streak and the presence of the apical half moon-shaped patch, and from L. laisalis, L. ethiopica and L. ugandensis sp. n. by the predominantly white forewing ground colour. Frons usually more strongly bulged than in other Leucinodes species, but 


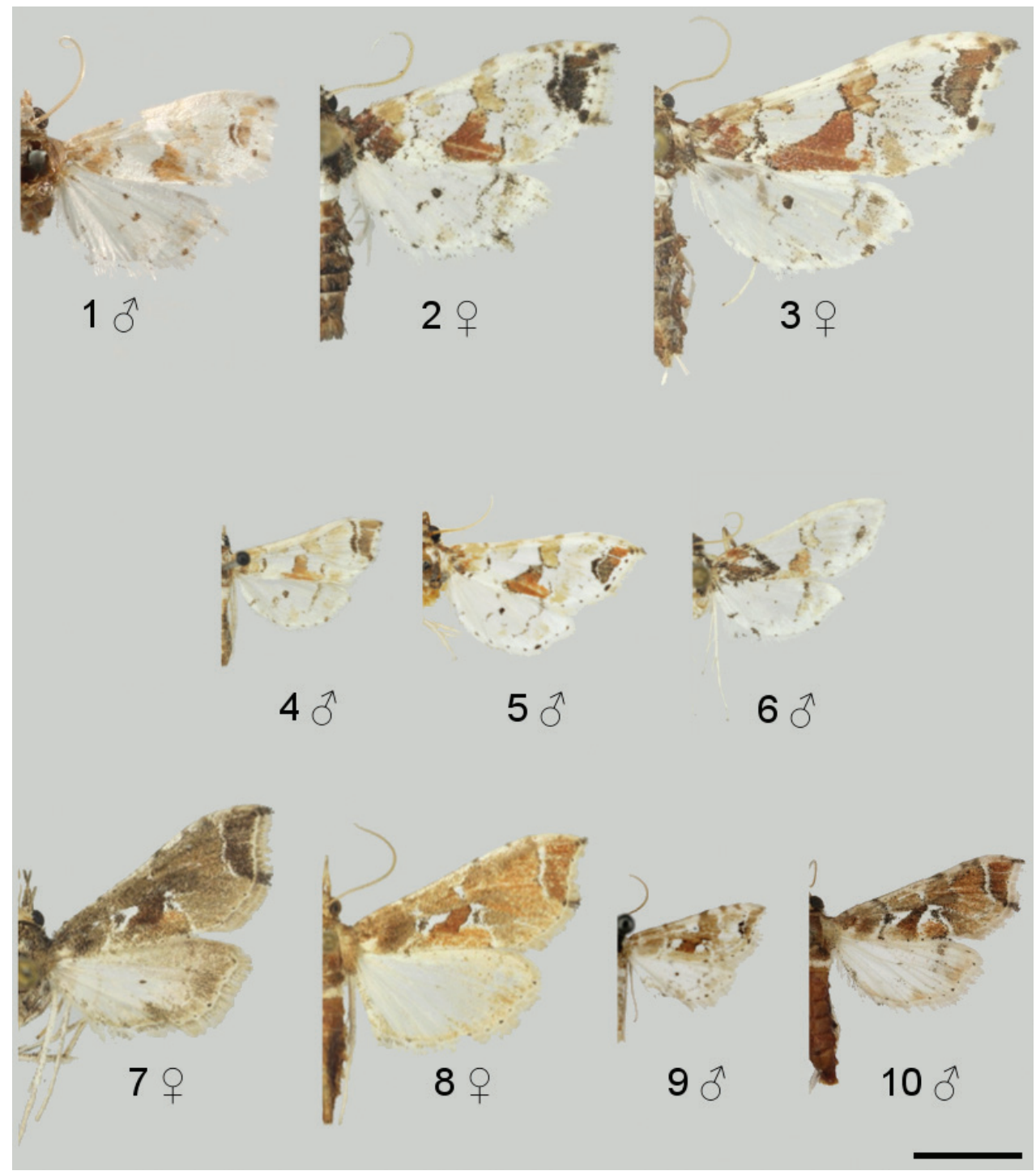

Figures I-I0. Adult specimens of Leucinodes. I Leucinodes orbonalis, syntype $\widehat{\sigma}$ (Bangladesh) $\mathbf{2}$ L. africensis + (Angola) 3 L. rimavallis + (DR Congo: Kivu) $\mathbf{4}$ L. pseudorbonalis $\widehat{\nearrow}$ (Uganda) $\mathbf{5}$ L. kenyensis, holotype $\widehat{\jmath}$ (Kenya) 6 L. malawiensis, holotype $\widehat{\partial}$ (Malawi) 7 L. laisalis 9 , greyish form (Tanzania) 8 L. laisalis + , brownish form (Tanzania) 9 L. ethiopica, holotype $\delta$ (Ethiopia) 10 L. ugandensis, holotype $\widehat{\sigma}$ (Uganda). Scale bar represents $5 \mathrm{~mm}$.

L. pseudorbonalis can be very similar in this feature. In male genitalia distinguishable by: dorsal margin of valval sacculus concave; apical sclerotized sacculus process elongated cone-shaped and crossing with the similar-sized fibula (as in L. pseudorbonalis); juxta slender, tapering (similar in L. africensis and L. rimavallis); saccus of vinculum short, less prominent. Female genitalia: antrum only slightly bulged, exocuticula without sclerotized strip. 
Redescription of adults. Head. As for the genus, with frons strongly bulged (Figs 11-12).

Thorax. As for the genus, with dorsal side brown.

Wings. Forewing length $\bigcirc 8.5-10.5 \mathrm{~m}$, + $9.5-12.0 \mathrm{~m}$; forewing ground colour white, basal area light- to dark brown, delimited by dark brown to grey antemedial line; median area with pale brown, faint proximal discoidal stigma; distal discoidal stigma pale brown, reaching from costa to forewing centre; central dorsum with prominent orange to dark brown L-shaped or triangular spot leading to forewing centre and often meeting with distal discoidal stigma; antemedial line sinuate, more or less distinct, but with prominent subcostal bulge; subapical half of termen with half moon-shaped brown to grey-grown spot; marginal line dotted; fringe and marginal line darkened at the tips of the half moon-shaped spot; hindwing ground colour white, internal area white, with discoidal spot, basicostally often with auxiliary spot; medial line sinuate, distal half approaching the discoidal spot, then turning towards dorsum; external area pale brown to gray; marginal line dotted.

Abdomen. First segment whitish, remainder brownish.

Male genitalia. As for the genus, apart from: juxta subulate, with short, broadly convex base, at $2 / 3$ length slightly broadened; valvae broad, relatively short, nearly triangular; costa simple, slightly convex, subapically with a short concave portion; fibula hooked, its widened base emerging ventrad of costa base; sacculus ventrally convex, dorsally concave, at distal end with spike-shaped, strongly sclerotized process, oriented dorsad and crossing with fibula; distal ventral valva margin granulated (ga in Fig. 13), valva apex rounded, strongly granulated; distal $2 / 3$ of ventral valva margin loosely covered with long thin setae; phallus simple, tapering posteriad, posterior apodeme dorsally elongate, ventrally with subapical, weakly serrated sclerite; ventral and dorsal portion of posterior apodeme separated by a slim, less strongly sclerotized region.

Female genitalia. As for the genus, apart from: anterior antrum with spoonshaped posteriad indentation, flanked on either side by a sclerotized portion (as in Fig. 31); sternite 8 anterior edge arched (ae in Fig. 31), with a sclerite process leading in each of the lateral pockets; both apophysis pairs simple, slightly curved.

Immature stages. Larva. MSD1 and MSD2 of meso- and metathorax usually on a shared pinaculum, earlier instars frequently have the MSD setae on separate pinacula on one or both segments; dorsal abdominal pinacula show apparent differentiation between West- and East-Asian populations: in live western specimens (e.g., from Pakistan), the abdominal D1 pinacula usually have an unpigmented cream coloured area near to their anteriomedian margin. This unpigmented area may be contiguous with the unmelanized cuticle surrounding the pinaculum or be surrounded by the melanized cuticle of the pinaculum (illustrated on A3-6 in Fig. 35); this cream white, unpigmented area may darken in preserved specimens, and in pre-pupae may be ringed in black. Eastern specimens (e.g., from Thailand) often have dark spots on at least some of the D1 pinacula (illustrated on A2 in Fig. 35); geographically intermediate populations (e.g., Sri Lanka) often show an intermediate form with black spots on occasional pinacula, and any unpigmented area is 


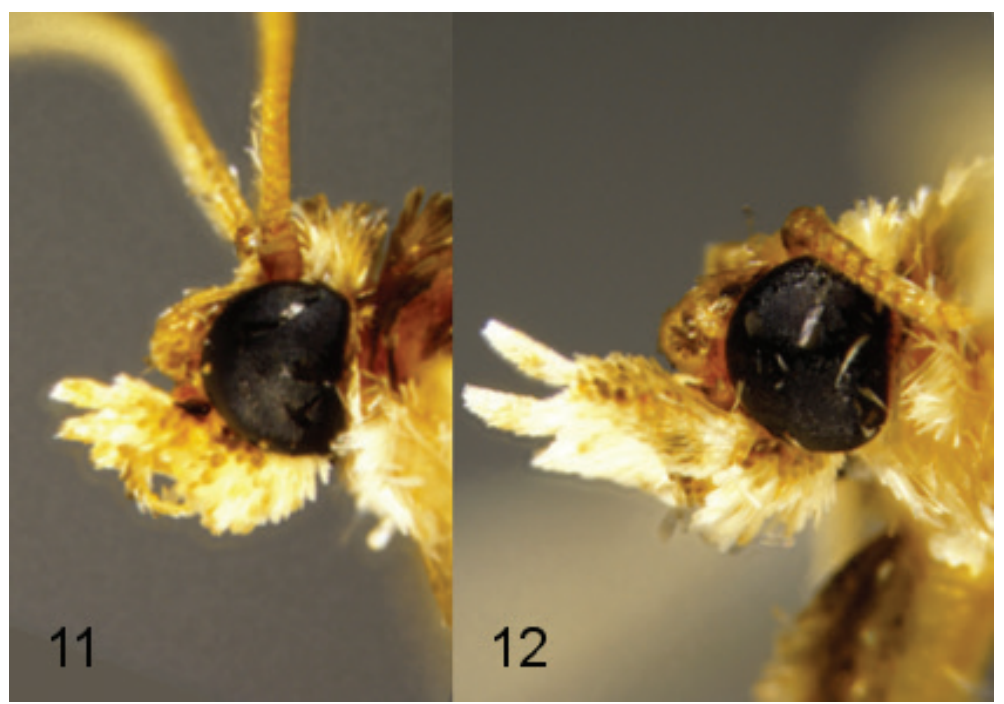

Figures I I-I 2. Head profiles of adult Leucinodes orbonalis. I I male I $\mathbf{2}$ female. Figures at same scale.

usually ringed with black pigmentation (illustrated on A7 in Fig. 35). East-Asian populations usually have mesally triordinal crochets, whereas the crochets of WestAsian populations are mesally biordinal. Pupa. Cremaster forms a variable shelf-like, sub-rectangular structure, much wider than long, usually with distinct distal corners and median notch; dorsal surface spinulose, with additional small but distinct spines which are variable in extent, form and number; cocoon of dark brown silk, may be white or beige when newly spun.

Distribution. India, Indonesia: Java (Guenée 1854), Sri Lanka (Walker 1859, Moore 1885), Myanmar (Burma), Andaman Islands (Pagenstecher 1900), Bangladesh, Brunei, Cambodia, China, Japan, Laos, Malaysia, Nepal, Pakistan, Philippines, Singapore, Taiwan, Thailand, Vietnam (CABI 2012a), Australia (Shaffer et al. 1996); imported to Great Britain, the Netherlands (pers. comm. M. van der Straten), Denmark (pers. comm. O. Karsholt) and the U.S.A. (Boateng et al. 2005, Solis 2006).

Food plants. Solanaceae: Solanum melongena L., S. aculeatissimum Jacq., S. aethiopicum L., S. erianthum D. Don., S. anguivi Lam. (as S. indicum L.), S. integrifolium Poir., S. lycopersicum L., S. macrocarpon L., S. mammosum L., S. nigrum L., S. torvum Sw., S. tuberosum L., S. viarum Dunal, S. xanthocarpum Schrad., Physalis minima L., P. peruviana L., Capsicum annuum L. (van der Straten 2005; Hayden et al. 2013).

Remarks. Leucinodes orbonalis has previously been reported in Europe from the Netherlands (van der Gaag et al. 2005) and Great Britain (Agassiz 1983; Higgott 2009) as well as from the following African countries due to misidentification: South Africa (Walker 1859; Pagenstecher 1900; Kemal and Koçak 2007); Kenya (Poulton 1916); Ghana (for example, Frempong and Buahin 1977, Frempong 1979, Duodu 1986, Horna et al. 2007); Lesotho, Zambia and Zimbabwe (Kopij 2005); Burundi, Cameroon, Congo, Democratic Republic of the Congo, Ethiopia, Malawi, Mozam- 
bique, Nigeria, Rwanda, Sao Tome and Principe, Sierra Leone, Somalia, Tanzania and Uganda (CABI 2012a). We have not found a single specimen from Africa belonging to this species and therefore postulate that $L$. orbonalis does not occur in Africa.

\section{Leucinodes africensis sp. $\mathrm{n}$.}

http://zoobank.org/F8291E38-9C43-478D-8ED6-9C39EE507065

Figs 2, 14-15, 24, 32, 35, 38-39, 42-43

Type-locality. West Africa, 11 June 1848, H. S. Le Marquand leg.

Material examined. Type-specimen. Holotype $\delta^{\hat{\alpha}}$ [red-circled label] "Holo| type", "WEST AFRICA: | H.S. Le Marquand. | 11. xi. 48", BM Pyralidae slide 23118 (BMNH). - Additional material. GHANA. 1 ㅇ Kumasi, leg. J. D. G. Sanders, BMNH Pyralidae slide No. 23130 (BMNH); LIBERIA. $10^{\wedge}$ Kpaine, $7^{\circ} 10^{\prime} \mathrm{N} 9^{\circ} 07^{\prime} \mathrm{W}$, 12.viii.1953, leg. Dr W. Peters, BMNH Pyralidae slide No. 23148 (BMNH); CÔTE D'IVOIRE. 10 Abidjan, 19.xi.1952, leg. L. Sheljuzhko, prep. RM330 (ZSM); 10 B Bouaké, Inepa, 14.-15.vi.1983, col. Stam, prep. RM693 (RMCA); 1 ㅇ Bingerville, 11.vi.1961, leg. J. Decelle, prep. RM704 (RMCA]; 1 ㅇ Mont Nimba, Xealé, 6.ii.1959, leg. M. Condamin \& R. Roy, prep. RM743 (MNHN); NIGERIA. 1 우 Lagos, 31.viii.1987, leg. Boorman, BMNH Pyralidae slide No. 23127 (BMNH); 1 ex. Oyo, Ibadan, International Institute of Tropical Agriculture, 7.501N 3.906E, 240m, 15.iii.2006, leg. S.E. Miller \& T.M. Kuklenski, DNA Barcode USNM ENT 196725 (USNM); GABON. 10 Ntoum, xii.1986, leg. A. Pauly, prep. RM685 (RMCA); DR CONGO. $10^{\Uparrow}$ Sankuru, Dimbelenge, i.-ii. 1957, leg. M. Fontaine, prep. RM697 (RMCA); 19 Elisabethville, 20.ii.1934, leg. Ch. Seydel, prep. RM696 (RMCA); ANGOLA. $1 \delta^{\wedge} 3$ q prov. Uíge, Negage, market, $7^{\circ} 45^{\prime} 39.4^{\prime \prime S} 15^{\circ} 16^{\prime} 00.6 " \mathrm{E}, 1213 \mathrm{~m}$, 21.iii.2013, fruits of Solanum aethiopicum, e.l. 19., 20., 21.iv.2013, leg. M. Nuss, $1 \widehat{\delta}^{\lambda}$ prep. RM643, DNA vouchers SMTD Lep1562 \& Lep1563 (SMTD); 2 + same data, but 30.i.2014, fruits of Solanum aethiopicum, e.l. 16.ii.2014, leg. M. Nuss (SMTD); WEST AFRICA. 10 ii.-xi.43, leg. H. S. Le Marquand, BMNH Pyralidae slide No. 23118 (phallus lost) (BMNH); TANZANIA. 2 ㅇ Oldeani, 22.x.1961 \& 9.xii.1961, leg. J. Killand, preps RM334 \& RM634 (ZSM); THE NETHERLANDS (IMPORT). $1 \hat{\sigma}^{\hat{\gamma}}$ Schiphol (Amsterdam), import Ghana, 18.ix.2009, ex larva 22.ix.2009, ex pupa 1.x.2009, leg. P. Dekker, det. M v. d. Straten, prep. RM501, DNA voucher SMTD Lep946, DNA Barcode BC MTD 01816 (NPPO); 1 S Schiphol (Amsterdam), import Ghana, 18.ix.2009, ex larva 23.ix.2009, ex pupa 1.x.2009, leg. P. Dekker, det. M. v. d. Straten, prep. RM640 (NPPO); GREAT BRITAIN (IMPORT). 1 $\widehat{\jmath}$ London Airport, import Zimbabwe (Rhodesia), 1965; $1 \delta^{\lambda} 1 q$ import Nigeria, ex tomatoes, London Airport xi. 1965 (FERA); for additional FERA material see Suppl. material 2.

Diagnosis. The frons is less strongly bulged than in $L$. orbonalis. In wing pattern this species is indistinguishable from those of $L$. orbonalis, L. rimavallis, $L$. pseudorbonalis, L. kenyensis and "Leucinodes spp.", but distinguished from L. malawiensis by 


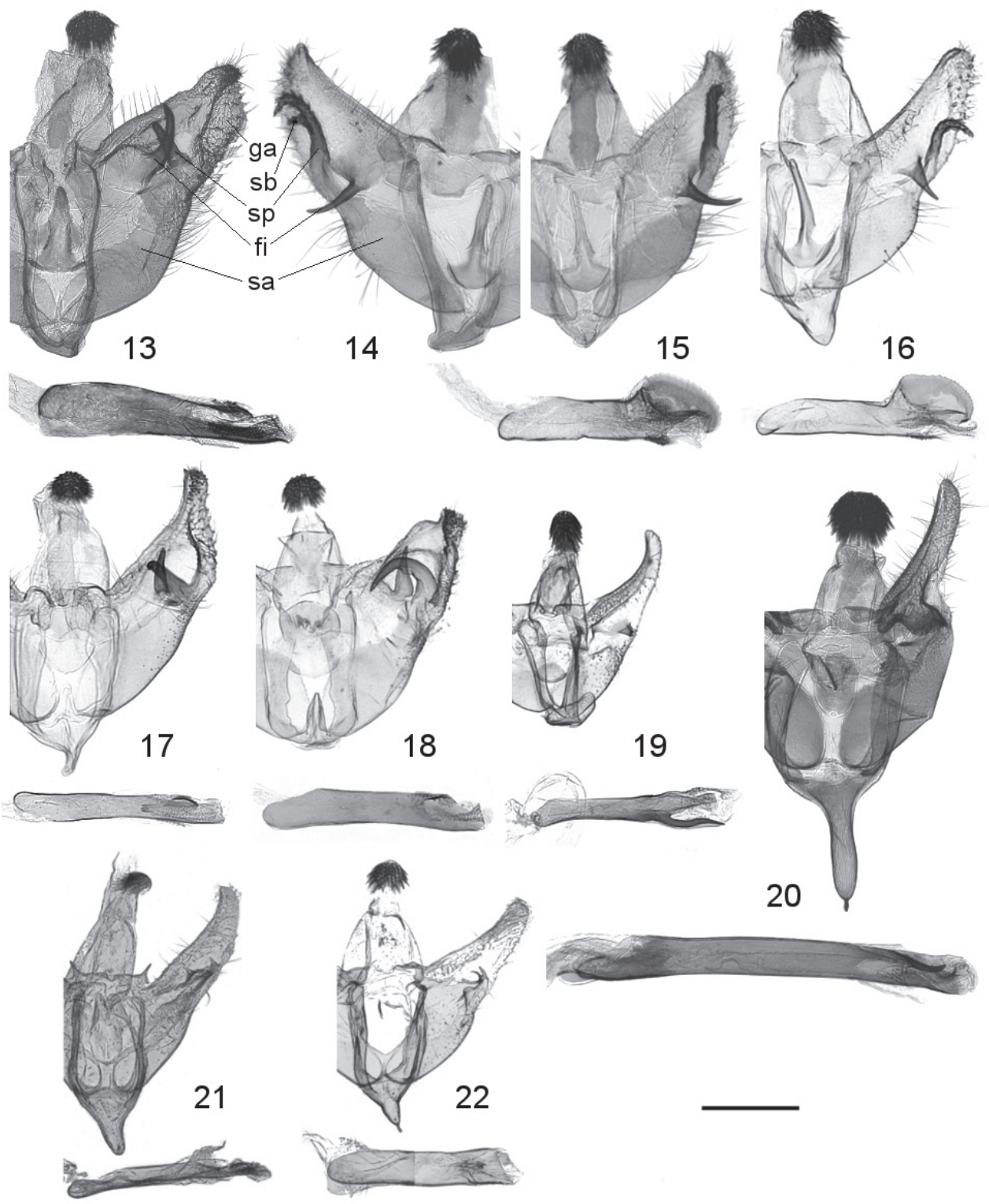

Figures 13-22. Male genitalia. I3 Leucinodes orbonalis, Vietnam (prep. RM503) I4 L. africensis, twobranched sacculus process, Côte d'Ivoire (prep. RM330, phallus omitted) 15 L. africensis, single-branched sacculus process, Ghana (import) (prep. RM501) 16 L. rimavallis, Kenya (prep. RM667) 17 L. pseudorbonalis, Uganda (prep. RM705) I8 L. kenyensis, Zimbabwe (prep. RM694) 19 L. malawiensis, Malawi (prep. RM683) 20 L. laisalis, South Africa (prep. RM504) 2 I L. ethiopica, Ethiopia (BMNH Pyralidae slide 23138) 22 L. ugandensis, Somalia (BMNH Pyralidae slide 23140); phallus mirrored. Abbreviations: fi fibula, ga granulated area, sa sacculus, sb side branch of sacculus process, sp sacculus process. Scale bar represents $500 \mu \mathrm{m}$. 
the absence of the forewing basal transversal streak and the presence of the apical half moon-shaped patch, and from L. laisalis, L. ethiopica and L. ugandensis by the predominantly white forewing ground colour. In male genitalia it is distinguished by: the long ventrad fibula (as in L. rimavallis, short and triangular in L. malawiensis, broad and stout in L. laisalis); the elongate, straight or hook-shaped, sometimes branching distal sacculus process projecting towards the valva apex (similar in L. rimavallis); the apically thin, subulate juxta (similar in L. rimavallis); the prominent oval saw blade-shaped sclerotization of the posterior phallus apodeme (as in L. rimavallis); it is distinguished from $L$. rimavallis by the longer, more curved fibula with a slender base, the elongate distal sacculus process, which spans more than half the distance fibula base-valva apex, is straight or hook-shaped and sometimes exhibits a side branch, and the pointed valva apex (rounded in L. rimavallis). Female genitalia resemble those of $L$. pseudorbonalis in having a swollen antrum, but they lack the posterior constriction of the ostium bursae.

Description of adults. Head. As for the genus, with frons moderately bulged, base of each meron of labial palps with white scales.

Thorax. As for the genus, with dorsal side brown.

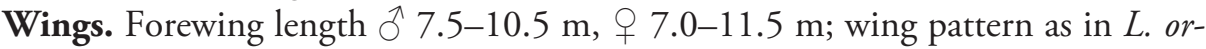
bonalis.

Abdomen. First segment whitish, remainder brown to grey.

Male genitalia. As for the genus, apart from: juxta base broad, semicircular, apical $2 / 3$ of juxta thin, subulate; valvae broad, forming an oblong triangle; sacculus process porrect towards valva apex or apically bent, apex acanthaceous, sometimes with a similarly acanthaceous subapical side branch $(s b$ in Fig. 14); ventrad fibula thin, spine-like, curved, crossing distal sacculus anterior to the sacculus process; valva apex pointed; posteriodorsal phallus apodeme with prominent oval saw blade-like sclerite, posterioventral apodeme with posteriodorsad oriented tapering process.

Female genitalia. As for the genus, apart from: colliculum-antrum complex in sagittal plane of sigmoid shape; dorsal surface of antrum exocuticle with longitudinal sclerotized strip running from sternite 8 , bearing transverse ridges (Fig. 32); sternite 8 with anteriomedian recess, anteriolateral edges slightly dentate; apophyses anteriores with broadened central portion.

Immature stages. Larva. Final-instar larvae of $L$. africensis and $L$. orbonalis cannot be definitively separated. In final instars of live specimens of $L$. africensis, the majority of the abdominal D1 pinacula have a dark pigmented spot on the anteriomedian margin (illustrated on A2 in Fig. 35), although in the occasional pinaculum this is replaced by an unpigmented area, which can be contiguous with the unmelanized integument surrounding the pinaculum or separated from it by the melanized cuticle of the pinaculum; crochets are mesally triordinal, as in the East-Asian populations of $L$. orbonalis. Pupa. length ca. $8.5 \mathrm{~m}$; no consistent features separate the pupae of $L$. orbonalis and $L$. africensis.

Etymology. Latinized africensis, derived from the continent of Africa from where the type material originates and referring to the widespread distribution of this species on the African continent. 

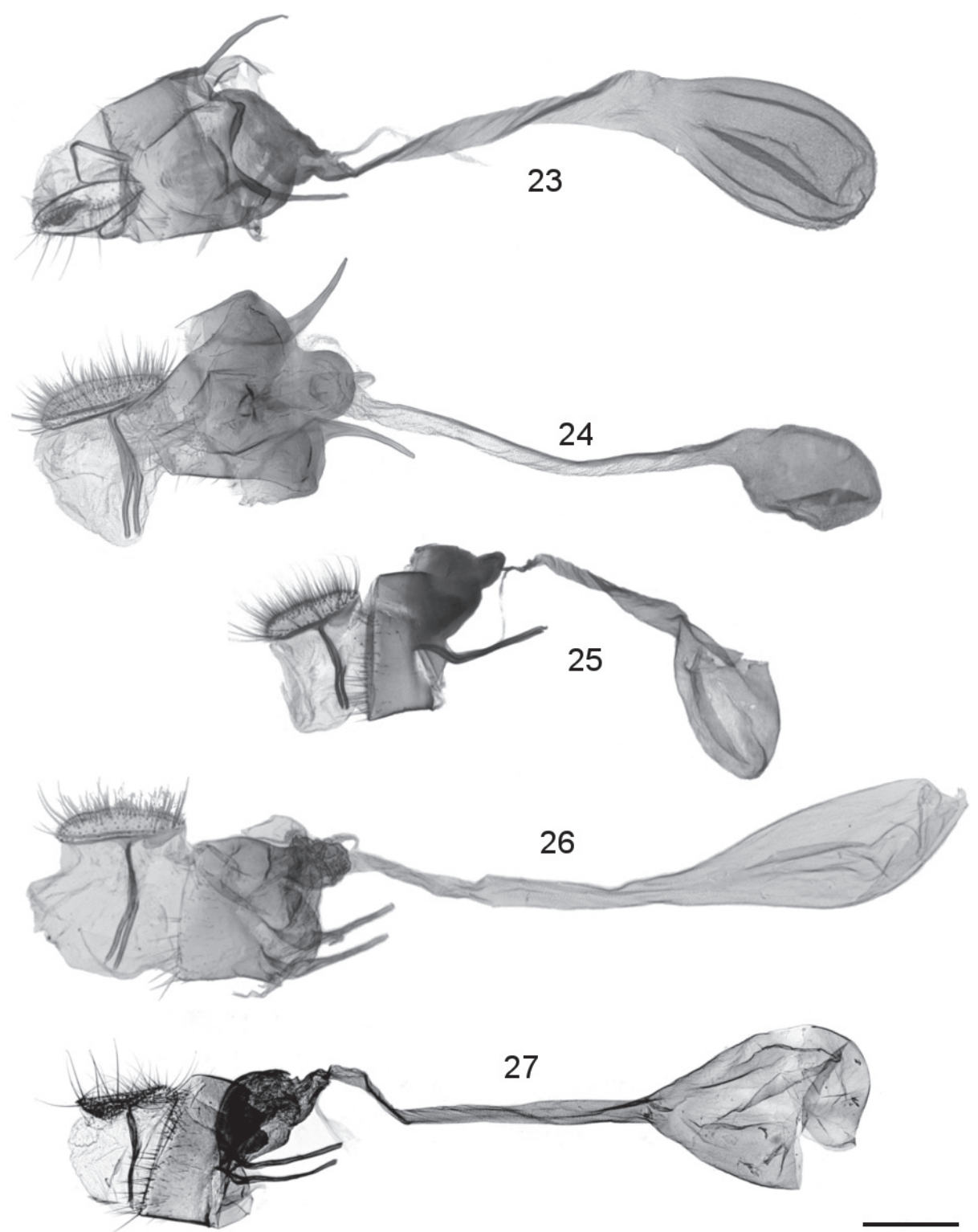

Figures 23-27. Female genitalia. 23 L. orbonalis, Thailand (import) (prep. RM642), ventral view $24 L$. africensis, Ghana (prep. RM640), ventral view 25 L. rimavallis, Kenya (prep. RM666, SMTD Lep1592), lateral view 26 L. pseudorbonalis, Uganda (prep. RM706), lateral view 27 L. kenyensis, Kenya (prep. MN1134), lateral view. Scale bar represents $500 \mu \mathrm{m}$.

Distribution. Known from West Africa (Côte d'Ivoire, Ghana, Liberia, Nigeria), Angola, DR Congo, Gabon, and Tanzania; intercepted with plant imports from Ghana and Zimbabwe to Great Britain and the Netherlands. At least in the southern DR Congo (Lubumbashi) L. rimavallis occurs sympatrically with $L$. africensis. 
Foodplants. Solanaceae: Solanum aethiopicum L. (Angola, leg. Nuss 2013), S. lycopersicon L., S. melongena L.

Remarks. This species is very similar to $L$. rimavallis, but both COI Barcoding data and constant morphological differences in genitalia separate the two species.

\section{Leucinodes rimavallis $\mathrm{sp} . \mathrm{n}$.}

http://zoobank.org/F7EFC84B-D824-420F-8D0D-F5D0FF026CE2

Figs 3, 16, 25

Type-lacality. Kenya, Mt Elgon, $01^{\circ} 07^{\prime} 06^{\prime \prime N}$, 34²41'30"E, February 1952, T. H. E. Jackson leg.

Material examined. Type-specimen. Holotype $\widehat{\partial}$ [red-circled label] "Holotype", "Mt Elgon | Kenya | Feb. 1952 | T.H.E. Jackson", "Pres. by | Coryndon Mus. | B.M. 1961-696.”, B.M. Pyralidae Genitalia slide No. 23119 (BMNH). - Additional material. RWANDA. 10 Gisenyi (Kisenyi), 30.iv.1957, leg. M. Fontaine, prep. RM698 (RMCA); BURUNDI. $2 \hat{\jmath}$ Kitega, 30.iv.1968 \& 31.v.1969, leg. M. Fontaine, preps RM702 \& RM703 (RMCA); KENYA. 10 Central Province, Castle Forest Lodge (S slope of Mt Kenya), 2050m, 0²1'15"S 35¹8'12"E, 20.xi.2009, prep. DJLA1337 (coll. DJLA); $1 \widehat{\delta}^{\lambda}$ Central Province, Gatamayu Forest, $0^{\circ} 58.45^{\prime} \mathrm{S}$

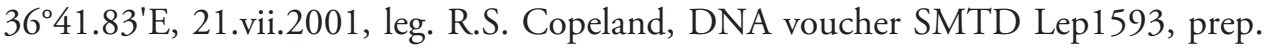
RM667 (RMCA); $10^{\uparrow}$ Central Province, Gatamayu Forest, $0^{\circ} 58.45^{\prime} \mathrm{S} 36^{\circ} 41.83^{\prime} \mathrm{E}$, 2284m, 17.viii.2002, leg. R. Copeland, prep. RM684 (RMCA); 1 q Coast Province, Buda Forest, $4^{\circ} 27.79^{\prime} \mathrm{S} 39^{\circ} 24.20^{\prime} \mathrm{E}, 25$. iv.2002, ex fruits Withania somnifera, leg. R.S. Copeland, DNA voucher MTD Lep1592, prep. RM666 (RMCA); 19 Fort-Hall [Murang'a], 1330 m, i.1912, leg. Alluaud \& Jeannel, prep. RM742 (MNHN); 1 + Taveta, 750 m, iii.1912, leg. Alluaud \& Jeannel, prep. RM744 (MNHN); 1 ㅇ Rurunga, 1550 m, i.1912, leg. Alluaud \& Jeannel, prep. RM745 (MNHN); 1 đ Western Province, Kericho, 2050m, 0²1'15"S 35¹8'12"E, 31.viii.1999, prep. DJLA1317

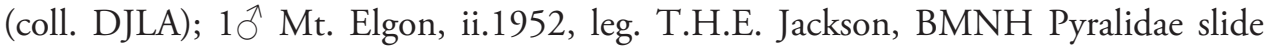
No. 23119 (BMNH); 1 ㅇ Mt. Elgon, i.1959, leg. T.H.E. Jackson, BMNH Pyralidae slide No. 23129 (BMNH); DR CONGO. 10 Ituri, Nioka, 5.ix.1953, leg. J. Hecq, prep. RM692 (RMCA); 10 Lubumbashi (Elisabethville), 13.x.1938, leg. Ch. Seydel, prep. RM695 (RMCA); 1 đ N. Kivu Lake, Rwankwi, iv.1948, leg. J. V. Leroy, prep. RM700 (RMCA); SOUTH AFRICA. 1 + Natal, prep. RM735 (MNHN); THE NETHERLANDS (IMPORT). $1 \hat{\delta}$ Barendrecht, import Uganda, 26.ii.2014, leg. Sluijs, on Solanum melongena, prep. RM756 (NPPO); $10^{\lambda}$ Rijnsburg, import Uganda, 12.ii.2014, leg. J. de Zeeuw, on S. melongena, prep. RM757 (NPPO).

Diagnosis. Frons is moderately bulged; in wing pattern this species is indistinguishable from L. orbonalis, L. africensis, L. pseudorbonalis, L. kenyensis and "Leucinodes spp.", but distinguished from $L$. malawiensis by the absence of the forewing basal transversal streak and the presence of the apical half moon-shaped patch, and from L. laisalis, L. ethiopica and L. ugandensis by the predominantly white forewing 


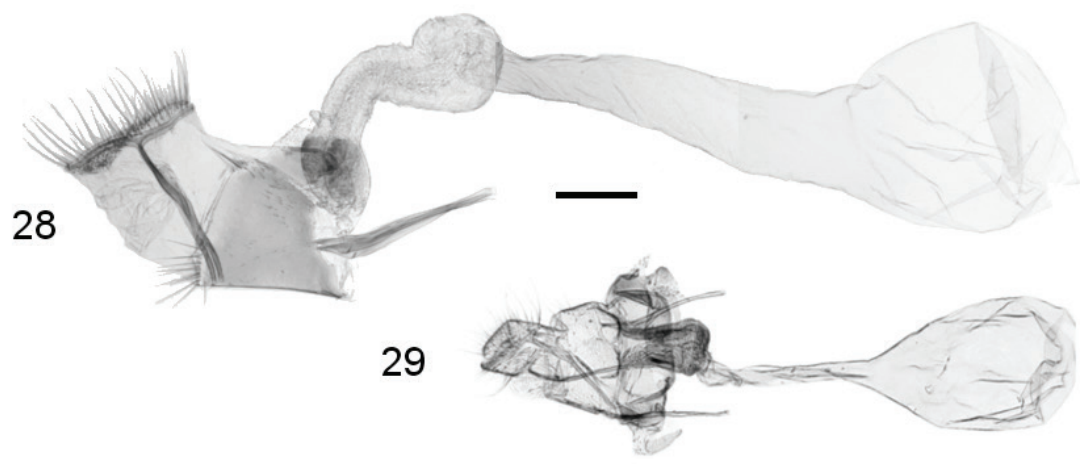

30
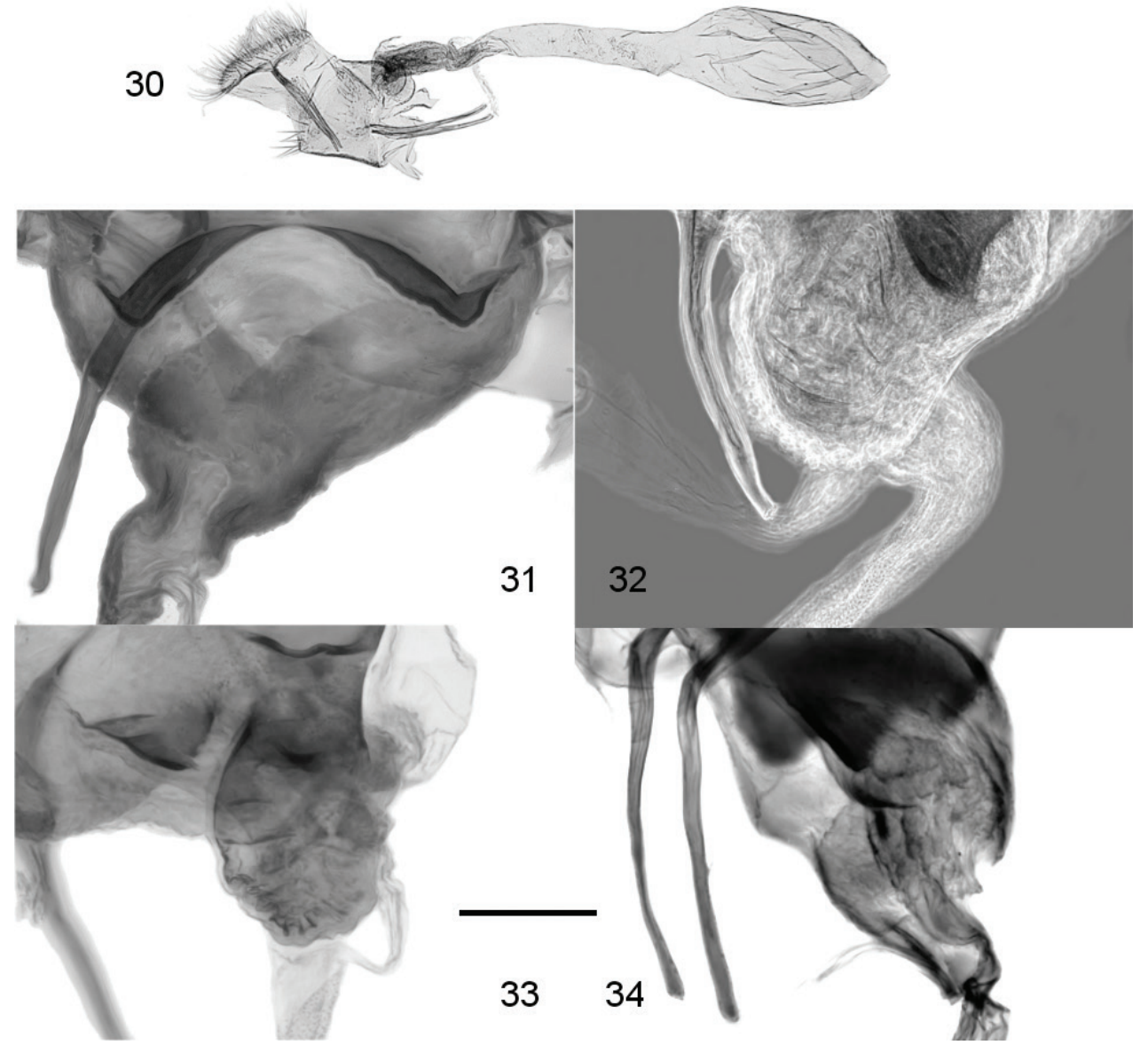

Figures 28-34. Female genitalia. 28 L. laisalis, Kenya (prep. RM308), lateral view 29 L. ethiopica, Ethiopia (BMNH Pyralidae slide 23139), ventral view 30 L. ugandensis, Somalia (BMNH Pyralidae slide No. 23137), lateral view $3 \mathbf{I}$ L. orbonalis, Thailand (import) (prep. RM642), ventral close-up of antrum region 32 L. africensis, Côte d'Ivoire (prep. RM743), dorsolateral close-up of antrum region (phase contrast filter) 33 L. pseudorbonalis, Uganda (prep. RM706), lateral close-up of antrum region 34 L. kenyensis, Kenya (prep. MN1134), lateral close-up of antrum region. Abbreviations: as antrum sclerotizations; Scale bar in $\mathbf{2 8 - 3 0}$ represents $500 \mu \mathrm{m}$ and in $\mathbf{3} \mathbf{I - 3 4}$ represents $200 \mu \mathrm{m}$. 
ground colour. In male genitalia it is distinguished by: the long ventrad fibula (as in L. africensis, short and triangular in L. malawiensis, broad and stout in L. laisalis); the granulate, hook-shaped distal sacculus process (similar in L. africensis, process smooth in L. kenyensis); the apically thin, subulate juxta (as in L. africensis, broad subulate in $L$. orbonalis); the prominent oval saw blade-shaped sclerotization of the posterior phallus apodeme (as in L. africensis); distinguished from L. africensis by the shorter, straight to slightly curved fibula with a broader base, the shorter, always hook-shaped distal sacculus process, and the rounded valva apex (pointed in L. africensis). Female genitalia have slender apophyses anteriores (as in L. orbonalis), the central antrum tube with a short, strongly sclerotized section (long strip in L. africensis and L. pseudorbonalis), and the anteriolateral edges of sternite 8 with triangular processes extending into the lateral antrum pockets (as in L. kenyensis).

Description of adults. Head. As for the genus, with frons moderately bulged.

Thorax. As for the genus, with dorsal side brown, tegula scales whitish-brown.

Wings. Forewing length $\delta 8.5-12.0 \mathrm{~mm}$, $+7.0-14.0 \mathrm{~mm}$; wing pattern as in $L$. orbonalis.

Abdomen. First segment whitish, remainder light to dark brown.

Male genitalia. As in L. africensis, but with the fibula short, more triangular and robust, straight or slightly curved; distal sacculus process short and always bent apically; valva apex rounded or stout.

Female genitalia. As for the genus, apart from: anterior antrum with short sclerotized section, central posterior antrum with diffuse weak sclerotization; sternite 8 on each side with anteriad triangular process extending into the lateral antrum pockets.

Etymology. From latin rima for 'rift' and vallis for 'valley', referring to the African Rift Valley, the main distributional area of this species (as far as known).

Distribution. Burundi, Eastern and Southern Democratic Republic of the Congo, Kenya, Rwanda, South Africa, Uganda (import).

Foodplants. Solanaceae: Solanum melongena L., Withania somnifera (L.) Dunal.

\section{Leucinodes pseudorbonalis sp. $\mathbf{n}$.}

http://zoobank.org/5B6C0A50-209B-407D-A689-4C8716D9EA18

Figs 4, 17, 26, 33

Type-locality. Angola, Huambo Province, Luimbale, Mt Moco, 1800-1900 m, $12^{\circ} 28^{\prime} \mathrm{S}, 15^{\circ} 10^{\prime} \mathrm{S}, 18$ March 1934 , K. Jordan leg.

Material examined. Type-specimen. Holotype $\widehat{\sigma}$ [red-circled label] "Holotype", "Mt. Moco, | Luimbale, | 1800 - 1900m., | 18 March 1934.”, “Angola | (Dr K. Jordan)”, "Rothschild | Bequest | 1939-1.”, BM Pyralidae slide 23135 (BMNH). Additional material. SENEGAL. 10 Dakar, 01.viii.1952, leg. A. Villiers (BMNH); UGANDA. $1 ð$ Masindi, 29.xii.1897, leg. Ansorge, BMNH Pyralidae slide No. 23125 (BMNH); $1 \widehat{\jmath}$ Labonga, Unyoro, 13.xii.1897, leg. Ansorge, BMBH Pyralidae slide 


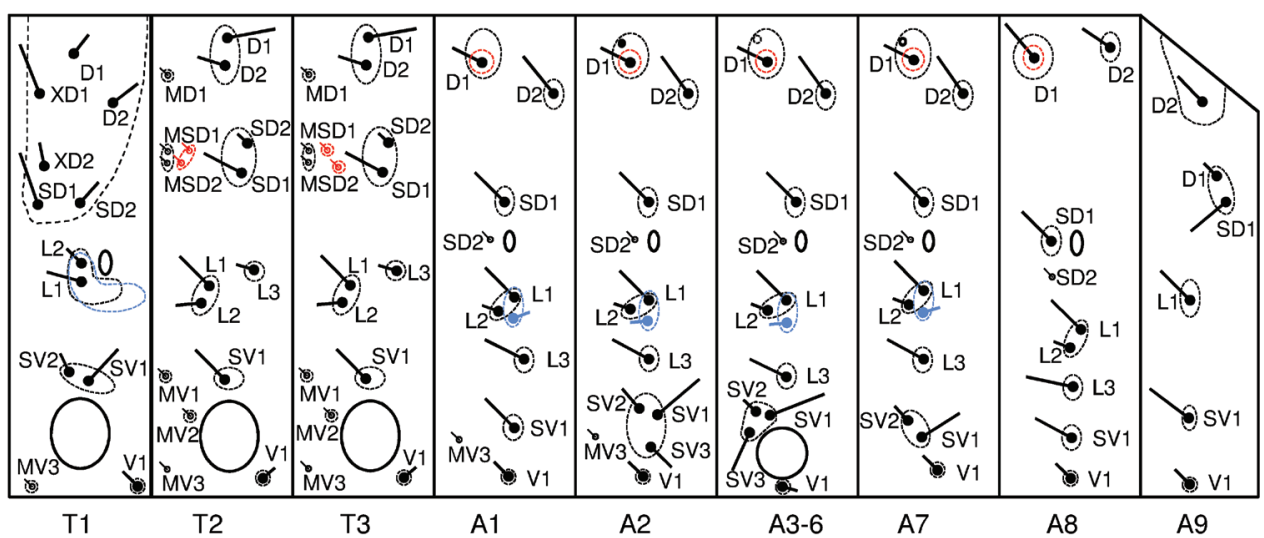

Figure 35. Chaetotaxy map of investigated Leucinodes larvae; blue elements illustrate variation found in L. orbonalis and L. africensis; red elements illustrate the differences found in L. laisalis compared to $L$. orbonalis and $L$. africensis.

No. 23126 (BMNH); 1 ^ Nabagulo Forest, 15 m from Kampala, 25.x.-06.xi.1921, leg. W. Feather, BMNH Pyralidae slide No. 23145 (BMNH); 10, Ruwenzori Range, Ibanda, 4,700ft, 4.-12.ix.1952, leg. D.S. Fletcher, BMNH Pyralidae slide No. 23146 (BMNH); 10 Masindi, 30.x.1897, leg. Ansorge, prep. RM707 (BMNH); $2 \hat{\jmath}$ Kampala, 1897, leg. Dr. Ansorge, BMNH Pyralidae slide No. 23149, prep. RM705 (BMNH); 1 ㅇ same data, prep. RM706 (BMNH); THE NETHERLANDS (IMPORT): 1 \& Barendrecht, import Uganda, 26.ii.2014, leg. Sluijs, on Solanum melongena, prep. RM758 (NPPO); GREAT BRITAIN (IMPORT). see Suppl. material 2.

Diagnosis. Frons is moderately to strongly bulged; Wing pattern indistinguishable from those of $L$. orbonalis, $L$. africensis, L. rimavallis, L. kenyensis and "Leucinodes spp.", but distinguished from $L$. malawiensis by the absence of the forewing basal transversal streak and the presence of the apical half moon-shaped patch, and from $L$. laisalis, L. ethiopica and L. ugandensis by the predominantly white forewing ground colour. In male genitalia the prominent dorsad fibula and the fibula-like sacculus process are roughly of same size and run parallel or cross each other (as in L. orbonalis, fibula and fibula-like sacculus process very small in L. ugandensis). Very similar to male genitalia of $L$. orbonalis, but valva tips slimmer and more acute, juxta with larger hemicircular base, elongated saccus tip and more prominent oval sclerite at posterior phallus apodeme. In female genitalia discriminated by the globular, posteriorly somewhat constricted antrum with a longitudinal, sclerotized exocuticular strip bearing transversal ridges (as in L. africensis).

Description of adults. Head. As for the genus, with frons moderately to strongly bulged.

Thorax. As for the genus, with dorsal side whitish.

Wings. Forewing length $\widehat{\gamma} 7.0-8.5 \mathrm{~mm}, \quad 99.0-11.0 \mathrm{~mm}$; wing pattern as in $L$. orbonalis.

Abdomen. First segment whitish, remainder orange-brown. 
Male genitalia. As for the genus, apart from: juxta oval to rectangular; valvae roughly rhombic; sacculus process claw-shaped, extending dorsad, parallel to or crossing with fibula; fibula slightly curved, spine-like, extending dorsad; posteriodorsal phallus apodeme with a small oval or semicircular sclerite, posterioventral apodeme with simple rodlike process.

Female genitalia. As for the genus, apart from: anterior antrum shortly coiled in coronal plane, with the exoculticle exhibiting a longitudinal sclerotized strip bearing transverse ridges (Fig. 33); sternite 8 intruding into the posteriorly somewhat constricted antrum, giving it a globular appearence.

Immature stages. Larva. Only one specimen available, examined live. Black spots present on dorsal pinacula; in the final instar, MSD1 and MSD2 on a shared pinaculum on both meso- and metathorax; crochets mesally triordinal.

Etymology. Composition of greek pseud(o) 'false' and orbonalis, meaning 'false orbonalis, referring to the similarities in external and male genital characters with $L$. orbonalis.

Distribution. Angola, Senegal, Uganda.

Foodplants. Solanaceae: Solanum aethiopicum L., S. melongena L.

Remarks. We found this species among material from Senegal, Uganda and Angola, leaving a considerable distribution gap in Central Africa.

Recently, several interceptions of larvae in solanaceous fruits imported from Uganda have been recorded in England (own observation) and the Netherlands (Marja van der Straten, pers. comm.). L. pseudorbonalis is one of the three African Leucinodes species intercepted at European ports of entry.

\section{Leucinodes kenyensis sp. $\mathbf{n}$.}

http://zoobank.org/C96D9272-2CEB-4916-948E-72C2999F35C3

Figs 5, 18, 26, 34

Type-locality. Kenya, Eastern Province, Marsabit District, Marsabit National Park Forest, 1158 m, 2 ${ }^{\circ} 13.996$ ' N, 37055.676'E, 29 December 2003, R. S. Copeland leg.

Material examined. Type-specimens. Holotype 10 "Kenya: Marsabit National | Park Forest. 1158 m. | 2²13.996'N 3755.676'E. | 29 Dec 2003, A\&M Coll. \#2636 | R.S. Copeland; ICIPE/USDA", "Reared from fruit: | Withania somnifera", DNA Barcode "USNM ENT 007/19337”, “1133 | Nuss prep. no.", coll. NMK. Paratypes 10̄, 1ㅇ, same data, DNA Barcodes USNM ENT 719338, 719339, Nuss prep. no. 1135 (1ㅇ NMK, $1 \overbrace{}^{\Uparrow}$ SMTD); 1 q Kenya, Laikipia Plateau, Mpala Research Centre, $0.293^{\circ} \mathrm{N} 36.899^{\circ} \mathrm{E}, 1650 \mathrm{~m}, 21 .-24 . v i .2005$, leg. S.E. Miller, DNA Barcode USNM ENT 719976, Nuss prep. no. 1134 (USNM). - Additional material. ZIMBABWE.

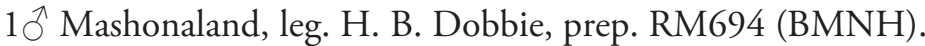

Diagnosis. Frons less strongly bulged than in L. orbonalis. Wing pattern indistinguishable from those of $L$. orbonalis, $L$. africensis, L. rimavallis, $L$. pseudorbonalis and Leucinodes spp., but distinguished from $L$. malawiensis by the absence of the forewing basal transversal streak and the presence of the apical half moon-shaped patch, and 


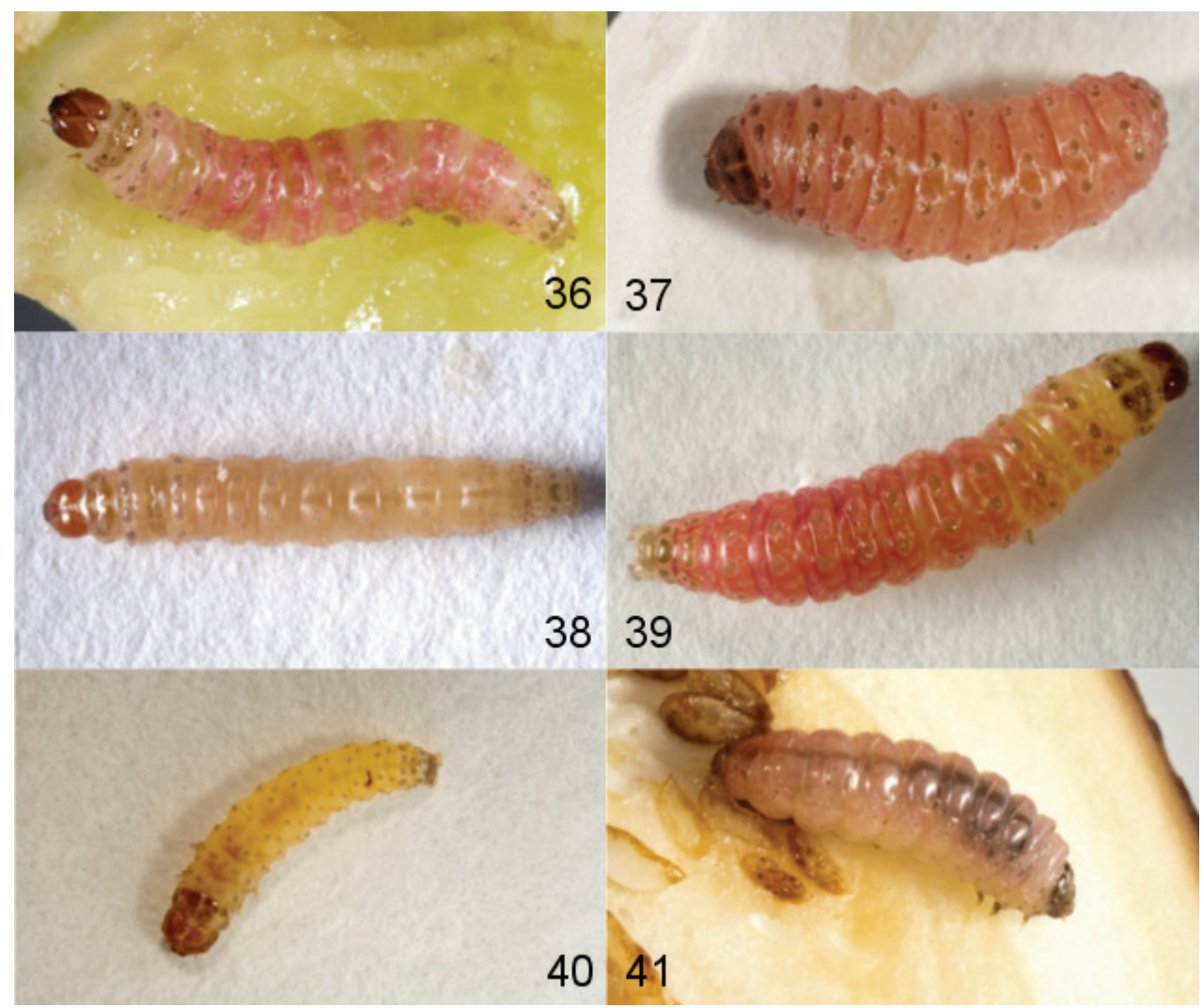

Figures 36-4I. Larvae of Leucinodes. 36-37 L. orbonalis $36 \mathrm{mid}$ instar 37 late instar 38-39 L. africensis 38 mid instar 39 late instar 40-4I L. laisalis 40 early instar 41 late instar.

from L. laisalis, L. ethiopica and L. ugandensis by the predominantly white forewing ground colour. Distinguished in male genitalia from all other Leucinodes species except "Leucinodes spp." (see below) by the prominent distal sacculus process arching anteriodorsally above the shorter, conical fibula. Distinguished from Leucinodes spp. by the more or less bulged subapical portion of costa (straight in Leucinodes spp.) and the weakly sclerotized basal section of the sacculus process (between sacculus and distal hook-shaped process) which is as wide as base of hook-shaped process (strongly sclerotized and narrower than base of hook-shaped process in Leucinodes spp.). Female genitalia resemble those of $L$. rimavallis in having an anteriad triangular process on each side of sternite 8 extending into the lateral antrum pockets, but the exocuticle of the anterior antrum forms a sclerotized tube (short sclerotized section in $L$. rimavallis).

Description of adults. Head. As for the genus, with frons slightly bulged.

Thorax. As for the genus, with dorsal side brown.

Wings. Forewing length $\widehat{\partial} 9.0 \mathrm{~mm}$, $99.0 \mathrm{~mm}$; wing pattern as in L. orbonalis.

Abdomen. First segment whitish, remainder light to dark brown. 
Male genitalia. As for the genus, apart from: saccus bent posteriodorsad (not an artifact of embedding); juxta oval to rectangular; valvae roughly triangular; costa subapically more or less bulged; ventral valva apex flipped over, covered with small tubercles; ventral valva edge smoothly rounded at sacculus; base of sacculus process broad, weakly sclerotized, leading over to a large, strongly sclerotized hook which encompasses the fibula dorsally; fibula conical, slightly curved, its base somewhat constricted, projecting dorsad; phallus similar to L. orbonalis, posteriodorsal apodeme with short dentate sclerite (sometimes indistinct), vesica with area of minute teeth.

Female genitalia. As for the genus, apart from: anterior antrum with tubular sclerotized exocuticle; sclerotized wall at antero-ventral edge of the ostium bursae which at rest closes the ostium bursae against abdominal segment 8 . This wall is not melanized and can be stained with chlorazol black. It is delimited dorso-laterally by sclerotized and melanized lobes arising from the anterior edge of segment 8 just ventral of the apophyses anteriores. Anterior to the sclerotized wall there is a small, melanized colliculum.

Etymology. The species is named after Kenya, the only country from where it is confidently recorded so far.

Distribution. So far only known from Kenya. The record from Zimbabwe needs confirmation by investigation of female specimens and molecular analysis.

Foodplants. Solanaceae: Withania somnifera (L.) Dunal.

Remarks. There are further male specimens with indistinctive wing pattern and very similar genitalia, but DNA Barcode data suggest that among them are at least two further species. For more information, see under Leucinodes spp.

\section{Leucinodes malawiensis sp. $\mathbf{n}$.}

http://zoobank.org/FECB8543-F50F-4CB3-A3D7-5C9ABAA3D9CC

Figs 6, 19

Type-locality. Malawi, Central Region, Lilongwe District, Ntchisi Forest Reserve, $1560 \mathrm{~m}, 13^{\circ} 18.99972^{\prime} \mathrm{S}, 34^{\circ} 02.99934^{\prime} \mathrm{E}, 18$ February 2004, L. Aarvik leg.

Material examined. Type-specimen. Holotype $\widehat{\sigma}$ "MALAWI Central | Region, Lilongwe District: | Ntchisi Forest Reserve | 1560 m 18. ii. 2004 | leg. L. Aarvik", DNA voucher SMTD Lep1617, prep. RM683 (NHMO).

Diagnosis. Distinguished from the other Leucinodes species by the dark, straightframed forewing base and the absence of the subapical mark of the forewing termen. The male genitalia are similar to those of Leucinodes ethiopica and L. ugandensis, but are distinct in the long spinoid process of the posterior phallus apodeme.

Description of adults. Head. As for the genus, with frons flat.

Thorax. As for the genus, with dorsal side brown.

Wings. Forewing length $\delta 8.5 \mathrm{~mm}$; forewing base dark brown, its outer margin a straight diagonal line from the costa to the maculation of the central hind margin, a triangular patch leading lateroposteriad from the costa with the costal half reddishbrown and the central tip white; outer median area with a faint brownish transverse 


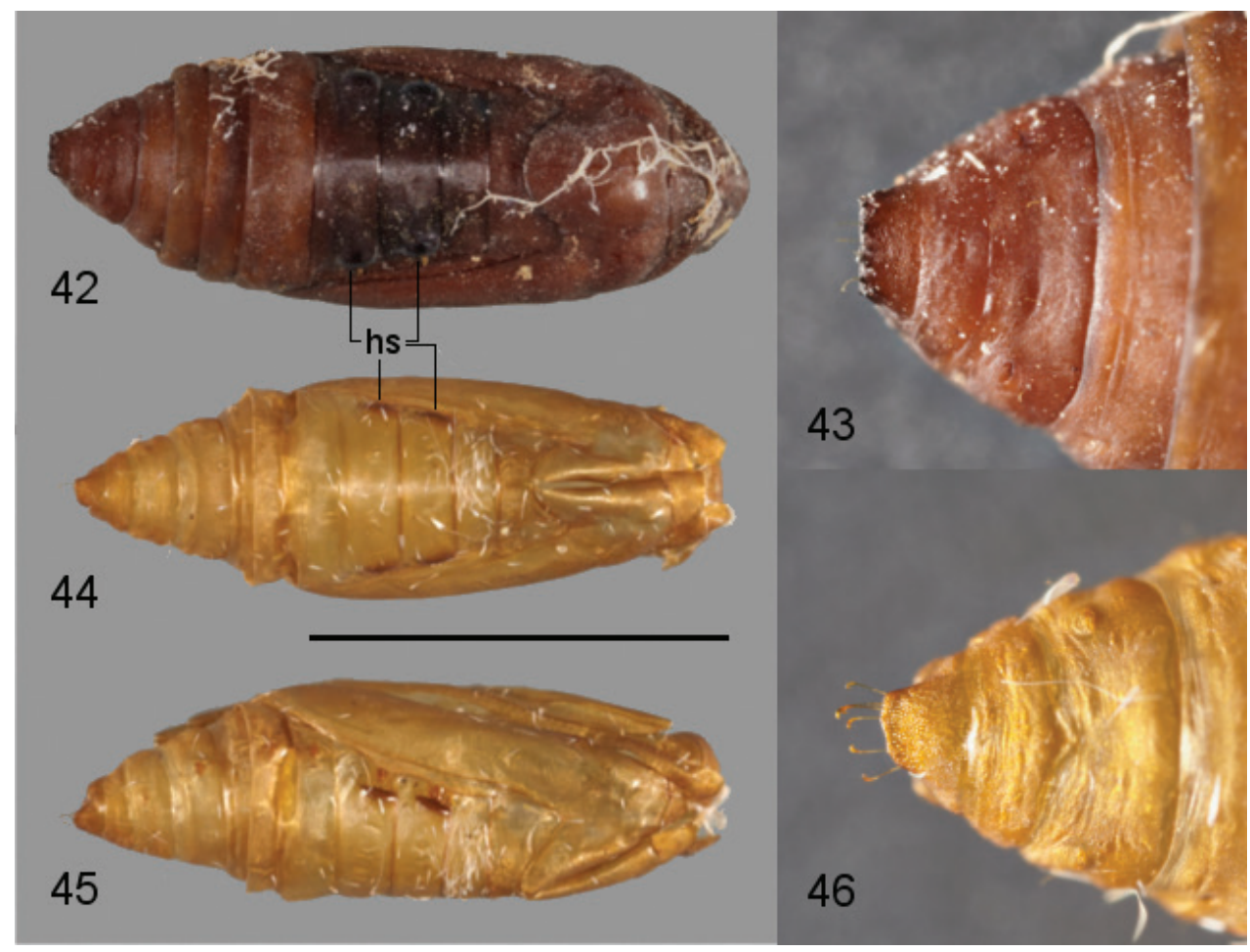

Figures 42-46. Pupae of Leucinodes. 42-43 L. africensis $\mathbf{4 2}$ dorsal view $\mathbf{4 3}$ close-up of cremaster 44-46 L. laisalis $\mathbf{4 4}$ dorsal view $\mathbf{4 5}$ lateral view $\mathbf{4 6}$ close-up of cremaster. Abbreviations: hs hood-like structures dorsal to spiracles on abdominal segments 2 and 3. Scale bar refers to $\mathbf{4 2 , 4 4}$ and $\mathbf{4 5}$ and represents $5 \mathrm{~mm}$.

streak; subterminal line indistinct except subapical thickening; apex white; hindwing antemedial line indistinct; dark discal spot; postmedial line clear at costal margin, fading out posteriad; anterior distal area with a faint brownish transverse streak; terminal wing veins dark-spotted.

Abdomen. Pale ochreous, first abdominal segment white, terminal segments brown.

Male genitalia. As for the genus, apart from: saccus elongated, U-shaped; juxta short, oval, twice as broad as long; valvae slender, tapering towards the dorsad bent apex; fibula small, triangular, oriented ventrad; sacculus process absent; phallus with a spinoid posteriad sclerotization emerging from the ventroposterior apodeme.

Female genitalia. Unknown.

Etymology. Latinized malawiensis from the country Malawi where the holotype originates.

Distribution. Malawi.

Foodplants. Unknown.

Remarks. Leucinodes malawiensis resembles species of the Neotropical genus Neoleucinodes Capps, 1948: It shares the prominent diagonal line in the forewing base with Neoleucinodes dissolvens (Dyar, 1914), but lacks the long, sabre-like cornutus in 
the phallus. The absence of the half moon-shaped pattern at the anterior half of the forewing's outer margin is also found in Proleucinodes Capps, 1948. In the COI Barcode Neighbor Joining tree L. malawiensis clusters with Neoleucinodes, but is weakly supported with 50\% Bootstrap support.

Leucinodes laisalis (Walker, 1859), comb. $\mathrm{n}$.

Figs 7-8, 20, 28, 35, 40-41, 44-46

Megaphysa laisalis Walker, 1859: 382-383. (Hampson 1899: 275 to Sceliodes)

= Daraba idmonealis Walker, 1859: 385-386.

= Hyamia subterminalis Walker, 1866: 1145.

= Daraba plenisignata Walker, 1866: 1977-1978.

= Leucinodes translucidalis Gaede, 1917: 398, syn. n.

Type-locality. South Africa, Cape of Good Hope

Material examined. Type-specimen. Holotype, sex unknown, [round white label with green border] "Type"; [round pale white label] [front] "C. G. | Hope", [back] "44 | 6"; [rectangular blue label] "Megaphysa | laisalis Wlk | Type" (BMNH). - Addi-

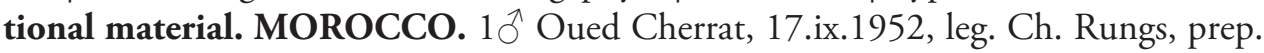
RM 734 (MNHN); SENEGAL. 10 Dakar, viii.1952, leg. A. Villiers, prep. RM736 (MNHN); CÔTE D’IVOIRE. 1 đ Bouaké, Inepa, 29.-30.xii.1983, leg. Stam, prep. RM688 (RMCA); NIGERIA. 1 ex. Oyo, Ibadan, International Institute of Tropical Agriculture, 7.501N 3.906E, 240m, 19.vi.2006, leg. G.M. Miller \& T.M. Kuklenski, DNA Barcode USNM ENT 676643 (USNM); KENYA. 10 Nairobi, Kiambu (Kyambu), 6000 ft, x.1916, leg. H. L. Andrewes, BMNH Pyralidae slide No. 23136 (BMNH); $10^{\Uparrow} 1$ ㅇ Kitui (Katoteni), 30.viii.2005, ex larva on Solanum incanum, adult 30.ix.2005, leg. Muli \& Okuku, preps RM301 \& RM308 (SMTD); 10ex. Laikipia County, Laikipia Plateau, Mpala Research Centre, 0.293N 36.899E, 1650m, 13.ii.1999 (1ex.), 20.iv.1999 (4ex.), 17.vii.1999 (3ex.), 23.xii.1999 (1ex.), 06.xii.2002 (1ex.), leg. S.E. Miller \& T.M. Kuklenski (5ex.), S.E. Miller \& R. O’Meara (4ex.), S.E. Miller (1ex.), DNA Barcodes USNM ENT 196697-196706 (USNM); 1ex. Matthews Range, 1.24N 37.29E, 1506m, 17.i.2004, leg. R.S. Copeland, DNA Barcode USNM ENT 719748 (USNM); TANZANIA. 1q Morogoro, Sokoine University Garden, 06 $50^{\circ}$ 'S 037³8'E, 05.vii.2009, leg. J. \& W. De Prins, prep. RM668 (RMCA); $10^{\Uparrow}$ Morogoro Distr. \& Town, 550-600 m, 14.xi.1992, leg. L. Aarvik, prep. RM686 (coll.

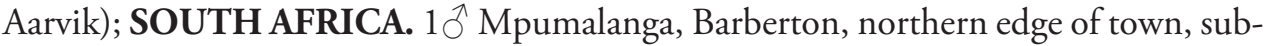
urban garden- and bushland, 610 m, 15./16.i.2007, leg. T. Karisch, DNA Barcode BC

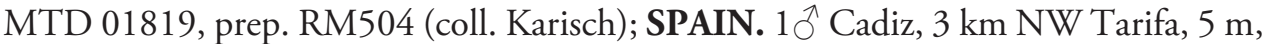
25.ix.1987, leg. P. Skou, prep. RM380 (ZMUC); GREAT BRITAIN (IMPORT). see Suppl. material 2 (Fera material).

Diagnosis. Distinguished from most other members of Leucinodes by the orangebrown to greyish forewing colour. Distinguished from L. ethiopica by the generally 
darker forewing colour with less amount of white. Differs from both L. ethiopica and L. ugandensis in: male genitalia with large, oval sacculus; broad, strongly sclerotized ventrad fibula; saccus well elongated; phallus coecum keeled, posteriodorsal apodeme with slim, fingerlike, well sclerotized process; female genitalia with antrum broad, its anterior end coiled, with exocuticle diffusely sclerotized.

Redescription of adults. Head. Frons slightly bulged; labial palps upturned, greyish to brown, first meron on ventral side with forward-directed tuft, third meron in males half as long as second meron, considerably longer in females; maxillary palps minute; haustellum well developed; eyes large, hemispherical; ocelli present; antennae ciliate, cilia considerably longer in males; vertex with creamy white scales; chaetosemata absent.

Thorax. Dorsal side brown with greyish and dark brown scales mixed in; ventral side grey to whitish; legs predominantly whitish or grey, epiphysis present; tibial spurs $0,2,4$ with outer spur $2 / 3$ the length of inner spur.

Wings. Forewing length $7.0-11.5 \mathrm{~mm}$, the females being somewhat larger; both sexes with one frenular bristle; forewing ground colour orange- to grey-brown, with the general Sceliodes wing pattern.

Abdomen. First segment whitish, remainder light-brown; older specimens often with darkened abdomen due to degeneration of abdominal fat body.

Male genitalia. As for the genus, apart from: vinculum saccus conspicuously elongated anteriad; juxta usually with small notch at median base; valvae emerging in narrow angle from vinculum; phallus with keeled coecum, posteriodorsal apodeme with slim, fingerlike, slightly curved and well sclerotized process, vesica with a short line of tiny cornuti.

Female genitalia. As for the genus, apart from: antrum long, tubular, anterior end coiled; apophysis pairs straight, apophyses anteriores with somewhat broader muscle attachment area at posterior quarter.

Distribution. In Africa known from Côte d'Ivoire, Ghana, Kenya, Morocco, Nigeria, Senegal, South Africa, Tanzania (own observations). Externally, L. laisalis is similar to L. ugandensis (see below), therefore literature records from other African countries than those listed here need verification. In Europe recorded from Spain, Portugal (Speidel 1996, Huertas Dionisio 2000; own observations) and Great Britain (own observations). The records from Great Britain certainly refer to interceptions and it is assumed that those from the Iberian Penninsula also do not refer to a native occurrence. Huertas Dionisio (2000) recorded the species from Solanum linnaeanum, a species native to southern Africa.

Food plants. Solanaceae: Solanum incanum L. (Kenya, leg. Muli \& Okuku 2005), S. anguivi Lam. ("S. sodomaeum L.,"), S. macrocarpon L., S. melongena L., S. linnaeanum Hepper \& P.-M. Jaeger, S. lycopersicon L. and Capsicum annuum L. (Hayden et al. 2013).

Immature stages. Larva. Generally very similar to $L$. orbonalis and $L$. africensis. On the metathorax the MSD setae are usually on separate pinacula, while the mesothoracic MSD setae are usually on the same pinaculum. The abdominal D1 pinacula 
are often smaller than those of L. orbonalis and L. africensis, and lack dark spots or unpigmented areas (see Ogunwolu (1978) for a detailed larval description and chaetotaxy). Pupa. length ca. $8.5 \mathrm{~mm}$; distal margins of cremaster usually evenly rounded, without distinct corners; spinulation of cremaster's dorsal surface a little coarser than dorsal spinulation on abdominal segment 9 dorsal surface, no distinct small spines as in L. orbonalis or L. africensis; cocoon of beige coloured silk that does not darken significantly over time.

Remarks. We found a significant DNA Barcode difference of 2.4-2.8\% uncorrected p-distance between the single South African specimen and the Kenyan and Ghanan/Nigerian Barcode clusters (Fig. 47; see also section 'DNA Barcoding' below). These differences in the DNA Barcode are not reflected in a divergent morphology of the clusters.

The record of L. laisalis from Belgium by Nyst (2004) is most probably a misidentification, since the illustrated imago resembles much more the whitish Leucinodes species. Apart from that, there is a European record of L. laisalis from Spain. Additionally, it is frequently intercepted with the import of solanaceous fruits in Great Britain.

Despite repeated search in the collection of the ZMHB, original material of Leucinodes translucidalis Gaede, 1917 from Tanzania, Tendaguru, could not be traced. According to the original description, this taxon can be regarded as conspecific with $L$. laisalis due to all details given in the original description. Especially the white triangle at the anterior line, another white triangle, though often somewhat inconspicuous, at the middle of costa, and the dark brown area below apex support the conspecifity with L. laisalis.

\section{Leucinodes ethiopica sp. n.}

http://zoobank.org/CC7E081A-7D4A-4C07-887F-4698DD8650EC

Figs 9, 21, 29

Type-locality. Ethiopia, Dire Dawa Region, Dire Dawa District, Dire Dawa, December 1934, H. Ulenhuth leg.

Material examined. Type-specimens. Holotype $\hat{\sigma}$ [red-circled label] "Holotype", "Dire Daoua, | Abyssinia, | December 1934. | (H. Uhlenhuth).”; 19 paratypes: $11 \hat{\delta}^{\lambda} 89$ same data as holotype, including one with BM Pyralidae | slide $231380^{\wedge}$ (BMNH). - Additional material. ERITREA. Asmara, 20.x.1905. leg. N. Beccari (without abdomen), 1 q same data except 28.i.1905 (BMNH); ETHIOPIA. 34 ex. same data as holotype except ii.1935, 4 ex. ditto except iv.1935, 7 ex. ditto except v.1935 including BM Pyralidae| slide 23139, 1 ditto except ix.1935, 2 ex. labelled Durleti [= Daleti] (BMNH); SAUDI ARABIA. 29 Taif (BMNH).

Diagnosis. This species' forewing colour has more ochreous than the whitish species of Leucinodes but less orange-brown to greyish than in L. laisalis and L. ugandensis. From L. ugandensis and L. laisalis it can be distinguished by the genitalia: in the male genitalia the transtilla arms each bear a dorsad spine; in the female genitalia the ductus 
bursae lacks the fine granular sclerotization, the antrum is strongly sclerotized, tubular and widest at its anterior end, and the oval ostial sclerites in the lateral antrum pockets are larger.

Description of adults. Head. Head and appendages pale ochreous.

Thorax. Pale ochreous.

Wings. Forewing length $6.0-8.0 \mathrm{~mm}$. Forewing mixed ochreous and white, an oblique dark ochreous fascia from above dorsum reaching halfway across wing, a blackish crescent before ochreous subterminal line, black dots along termen. Hindwing white, a small black discal spot, a faint irregular dark subterminal line, ochreous suffusion in outer part of wing in middle and towards apex.

Abdomen. Pale ochreous, first abdominal segment white.

Male genitalia. As for the genus, apart from: transtilla with short central notch, each transtilla arm with a dorsad spine; vinculum saccus with rounded tip; juxta oval to rectangular, apex with a short central notch; apex of valvae dorsally curved; small, spine-like dorsad fibula emerging from the central inner side of valva; sacculus with a fibula-like spiny dorsad process emerging ventrodistally of the fibula; posteriodorsal phallus apodeme with semicircular dentate sclerite.

Female genitalia. As for the genus, apart from: ductus bursae with fine longitudinal ripples; antrum tubular, with broader anterior end; apophyses anteriores at posterior half laterally broadened for muscle attachment.

Etymology. Latinized ethiopica from the country Ethiopia where the holotype originates.

Distribution. Eritrea, Ethiopia, Saudi Arabia.

Foodplants. Unknown.

Remarks. No COI Barcode sequences were obtained for this species.

\section{Leucinodes ugandensis sp. $\mathrm{n}$.} http://zoobank.org/533D9189-05DB-451D-ADB9-71AB3FD3DDD7

Figs 10, 22, 30

Type-locality. Uganda, Eastern Uganda Region, Serere District, Okulongo, 8 December 1958, W. R. Ingram leg.

Material examined. Type-specimens. Holotype $\widehat{\delta}$ [red-circled label] "Holo- | type", "[transversally written] 1608| "SERERE| Okulongo | 8 Dec. 1958| W.R.Ingram | ex Solanum sp.", "Pres. by | Com Inst Ent | BM1959 - 499”, "C.I.E. No. 16499”, with cocoon under specimen. 2 paratypes: 10 same data as holotype and "Pyralidae | Brit Mus | Slide No. | 14696”. 19 same data as holotype except 9 Dec. 1958 (BMNH). - Additional material. ETHIOPIA. 2へ Diredaua, n.w. of Harar, 1914, leg. G. Kristensen, 1 ㅇ Dire Dawa, Abyssinia, i.1935, leg. H. Uhlenkuth (BMNH); SOUTH SUDAN. 19 Tambura, Southern Bahr-al-Ghasal (BMNH); SOMALIA. 4仓 1ㅇ Mogadishu, 17.-26.xi.1985, 7.vii.1986, 19-20.viii.1986 and 23.vii.1986, leg. A.G. Parker, BMNH Pyralidae slides No. $23140 \& 23137$ (BMNH); $1 \overbrace{}^{\Uparrow}$ Hargeison, 


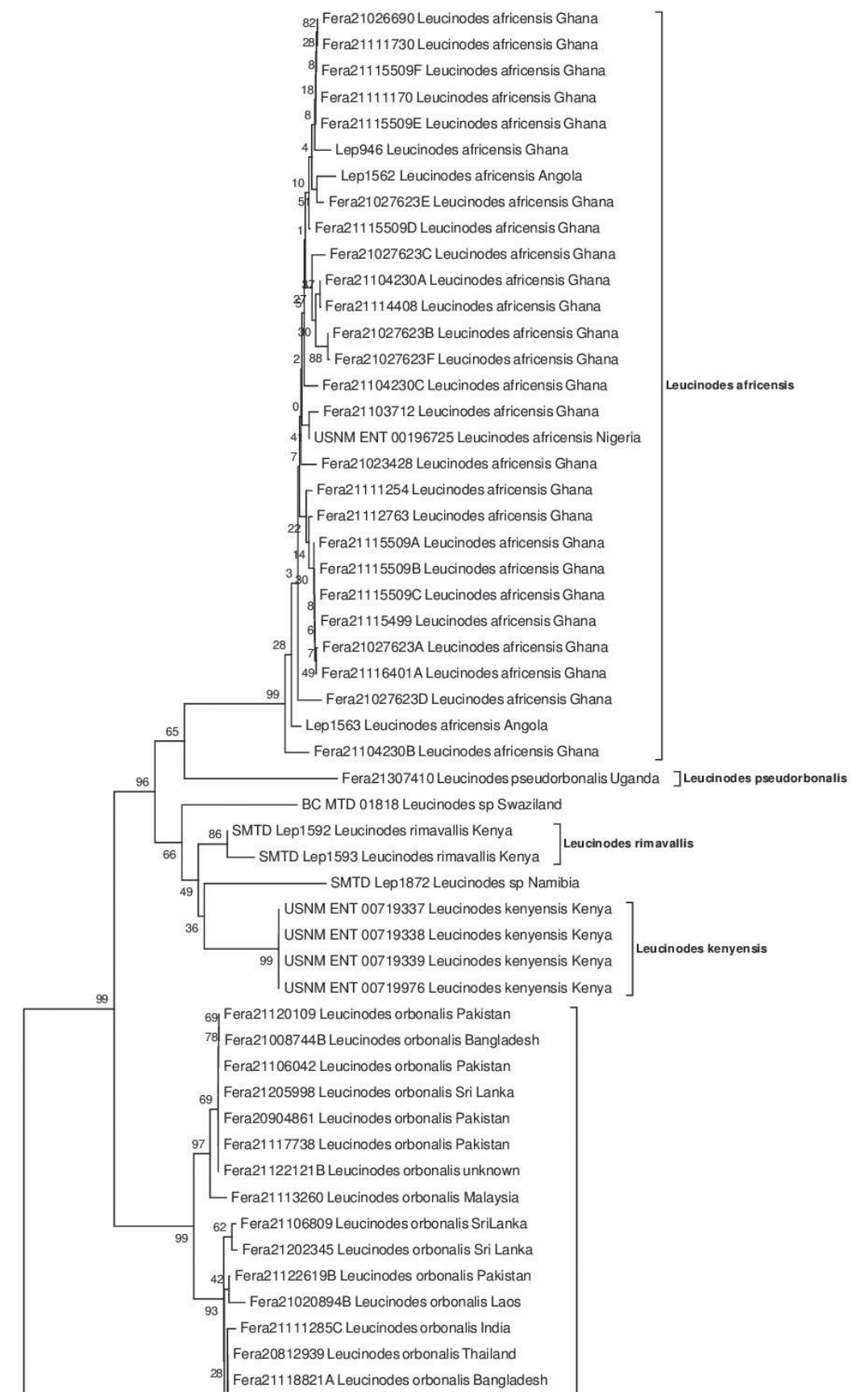

Figure 47. Neighbor Joining tree of COI Barcodes based on uncorr-p distances and rooted with Udea ferrugalis. Bootstrap support values derived from 1,000 Bootstrap replicates; scale bar represents $1 \%$ uncorr-p Barcode divergence. 


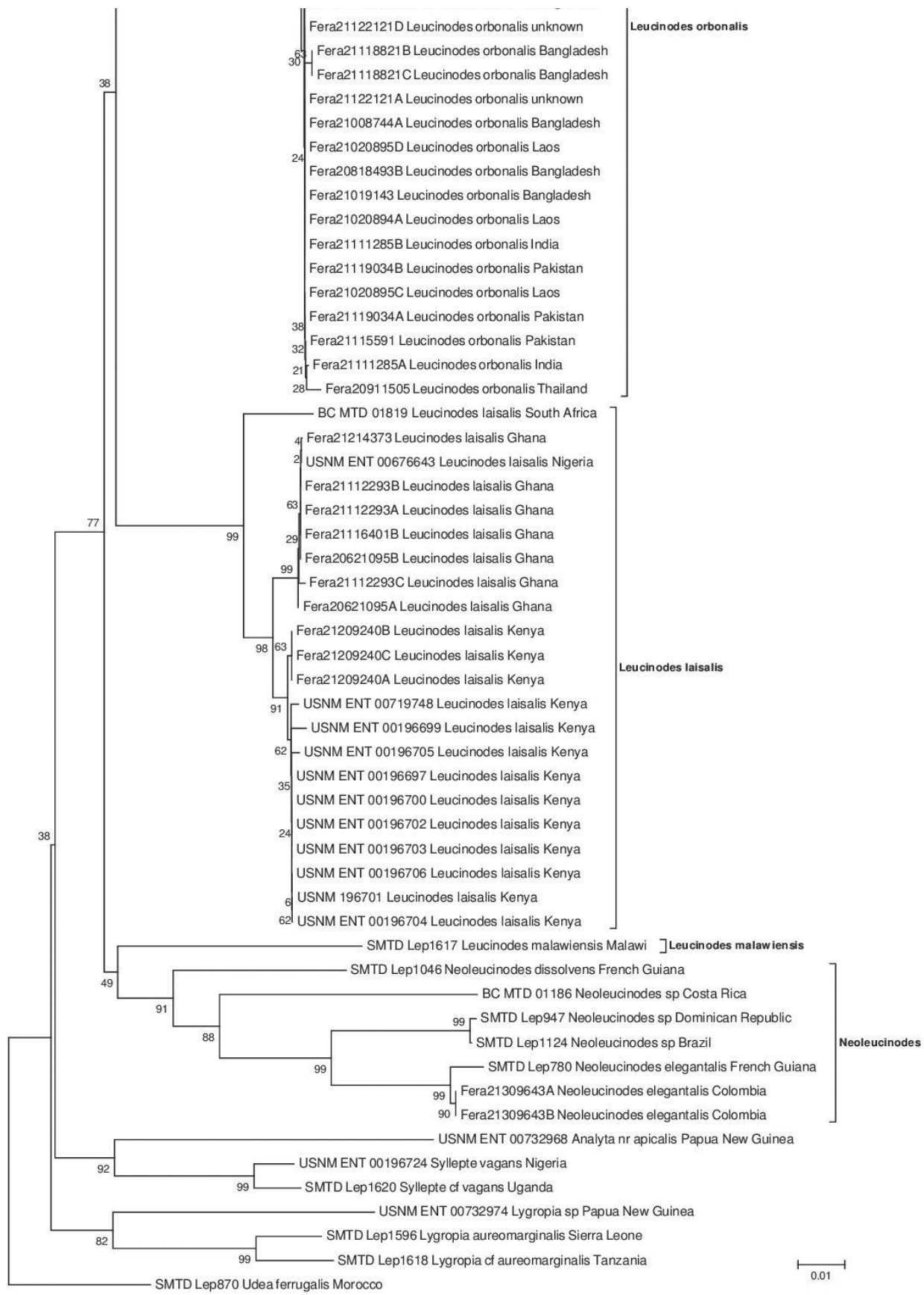

Figure 47. Continue. 
4300ft, v.1939, leg. M. Portal Hyatt (BMNH); KENYA. 1 \& Somaliland, Mandera, $47 \mathrm{~km}$ SW of Hubera, 3000ft, 13.xi.1908, leg. W. Feather (BMNH).

Diagnosis. Distinguished from the whitish species of Leucinodes and L. ethiopi$c a$ by the predominantly brown forewing ground colour with minor white patches. Distinguished from $L$. laisalis in the male genitalia: less strongly sclerotized, valvae triangular, fibula small, tooth-like, a similarly shaped distal sacculus process present, saccus process shorter, phallus much shorter, dorsoposterior apodeme without slim, finger-like process.

Description of adults. Head. Head and appendages pale fuscous, labial palpus short, erect.

Thorax. Pale fuscous, metathorax blackish fuscous.

Wings. Forewing length $6.5-11.5 \mathrm{~mm}$. Forewing pale fuscous, an oblique brown partial fascia at halfway with white markings on either side, an orange triangle on dorsum beyond halfway, apex deep brown, separated by a whitish line. Hindwing whitish, fuscous suffused near margin in middle and towards apex, a faint subterminal line in costal part of wing.

Abdomen. Abdomen first segment whitish, remainder orange-brown.

Male genitalia. As for the genus, apart from: small, hooked dorsad fibula emerging from the ventrocentral inner side of valva; distal sacculus with dorsad ridge forming a bulge, followed by a spiny, curved terminal process overlapping with the fibula; phallus vesica with several small spiny cornuti.

Female genitalia. As for the genus, apart from: diffusely sclerotized exocuticula reaching into posterior ductus bursae; lateral antrum pockets rather small.

Etymology. Latinized ugandensis from the country Uganda where the type specimens originate.

Distribution. Ethiopia, Kenya, Somalia, South Sudan, Uganda.

Foodplants. Solanaceae: Solanum sp.

Remarks. No COI Barcode sequences were obtained for this species.

\section{Leucinodes spp.}

Note. The following material contains male specimens from southern Africa with indistinctive wing pattern and very similar male genitalia to Leucinodes kenyensis. According to morphology, we could not separate these specimens from L. kenyensis. In contrast to the morphological data, two of these specimens, the single records from Namibia and Swaziland, have distinctive DNA Barcodes from L. kenyensis as well as from each other (Fig. 47). For the remaining specimens listed below, we did not obtain DNA Barcodes. In spite of the absence of further specimens for comparison, especially females, and the lack of convincing morphological differences, we are not going to describe these possibly distinct species here. This complex needs further study.

Material examined. KENYA. $1 \delta^{\lambda}$ Rift Valley, Naivasha, 1900m, 0 46'56"S 36²5'23"E, 5.xii.2011, leg. D.J.L. Agassiz, prep. DJLA 1318 (coll. DJLA); ZAMBIA. 
$1{ }^{\Uparrow}$ Chiwefwe, ii.1950, leg. N. Mitton, BMNH Pyralidae slide No. 23133 (BMNH);

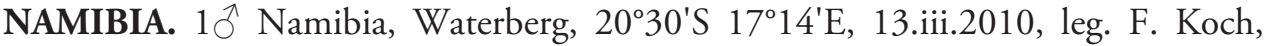
DNA voucher MTD Lep1872, prep. RM708 (ZMHB); SOUTH AFRICA. 10 Cape Province, Knysna, Wilderness, iv.1950, leg. H.B.D. Kettlewell, BM Pyralidae slide 23128 (BMNH); 10 Johannesburg, 21.iv.1906, leg. A.T. Cooke, BMNH Pyralidae slide No. 23144 (BMNH); 10 E. Cape Prov., Katberg, 4,000ft, 1.-15.i.1933, BMNH Pyralidae slide No. 23150 (BMNH); 10 ऊ̂ KwaZulu-Natal, Estcourt, leg. J.M.

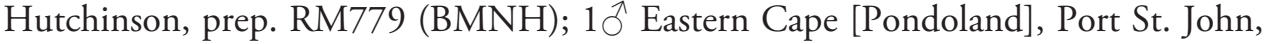
ix.1923, leg. R.E. Turner, prep. RM780 (BMNH); SWAZILAND. 10 LebomboMountains, Ndzevane Area near Nsoko, Acacia-rich bushland at the foot of the Lebombo Mountains, 23.-24.i.2007, leg. T. Karisch, DNA Barcode BC MTD 01818, prep. RM502 (coll. MTD).

\section{Taxa transferred to Leucinodes}

\section{Leucinodes cordalis (Doubleday, 1843), comb. n. (Margaritia)}

Leucinodes cordalis (Doubleday, 1843). Type locality: New Zealand.

= Daraba extensalis Walker, 1866 (synonymised by Hampson, 1899). Type locality:

New Zealand, Auckland.

= Eretria obsistalis Snellen, 1880 (synonymised by Hampson, 1899). Type locality:

Indonesia, Sulawesi [Celebes], Boelekomba; Bonthain.

= Sceliodes mucidalis Guenée, 1854 (synonymised by Hampson, 1899). Type locality: Australia.

Material examined. Syntype cordalis $\hat{\sigma}$ [circular white label with light blue border] "SYN- | TYPE", [circular white label] [front] "New | Zealand”, [back] “42 | 55”, [rectangular white label] "Margarita [sic!] | cordalis Doubld. | SYNTYPE | det. D.J. Carter, 1966", transparent capsule containing the head (BMNH).

Remarks. L. cordalis is known to occur in New Zealand, Australia, and Indonesia: Sulawesi (Snellen 1880, Dugdale 1988, Shaffer et al. 1996).

\section{Leucinodes raondry (Viette, 1981), comb. n. (Daraba)}

Type locality. Madagascar, Sambirano, Tsaratanana, Haut Sambirano, Besanetrikely Valley.

Remarks. This species was described in Daraba Walker, 1859, a genus that has previously been synonymised with Sceliodes Guenée, 1854 by Hampson (1899). The type specimen of Leucinodes raondry (Viette, 1981), comb. n. from Madagascar could not be traced at MNHN. According to the original description and the illustration of the species given therein (Viette 1981), this species agrees with the 
diagnostic wing pattern elements of Leucinodes, and we therefore consider it as correctly placed in this genus. It differs from L. laisalis in the larger size, the more ochreous grey tone and the reduced half moon-shaped subapical patch of the forewings (Viette 1981). None of the species described here as new have the prominent dark subapical patch in the hindwings of $L$. raondry, so that conspecifity with any of them can be ruled out.

\section{Leucinodes grisealis (Kenrick, 1912), comb. n. (misplaced) (Sceliodes)}

Type locality. Indonesia, Dutch New Guinea [West Papua], Arfak Mountains, $4000 \mathrm{ft}$

Material examined. Holotype $\widehat{\partial}$ [circular label with red border] "Type", [rectangular whitish label, handwritten, first two words underlined] "Sceliodes | grisealis | Kenrick. | TYPE.", [rectangular white label, handwritten] "SCELIODES | grisealis", [rectangular greyish label] "Arfak Mountains, | North New Guinea. | 4,000ft. Feb.-Mar., 1909. | C.B.Pratt.", [rectangular white label] "Kenrick Coll. | Brit.Mus. | 1928-34." (BMNH). Female unknown.

Remarks. Due to the synonymisation of Sceliodes, this species is provisionally transferred to Leucinodes, as no proper generic placement has been found. Compared to Leucinodes, several differences can be found in wing pattern of grisealis Kenrick, 1912: In the fore wing, the postmedian line is originating in the apex, and its median protrusion is closely approaching the termen; the half moon-shaped patch below apex is protruding beyond $\mathrm{M}_{3}$; in the hind wing, the postmedian line is originating closer to the apex and is running closer to the termen.

\section{Taxa excluded from Leucinodes}

\section{Analyta Lederer, 1863}

Analyta Lederer, 1863. Type species: Analyta albicillalis Lederer, 1863.

= Hyperanalyta Strand, 1918, syn. rev. Type species: Analyta pseudoapicalis Strand, 1918. Analyta apicalis (Hampson, 1896), comb. n. (Leucinodes). Type locality: India, Dharamsala. Sri Lanka.

= Analyta (Hyperanalyta) pseudoapicalis Strand, 1918 (synonymised by Shibuya, 1928).

Type locality: China, Taiwan, Anping.

Material examined. Types: Holotype albicillalis [circular white label with red border] "Type", [beige label with brown border and triangular edges] "Amboina | Doll.", [rectangular white label] "Felder | Collection.", [rectangular white label] "Rothschild | Bequest | B.M.1939-1.”, [rectangular beige handwritten label] "Amboina| Dol.”, [rec- 
tangular beige handwritten label] "Analyta | albicillalis m", [rectangular brown label with central white area, roundly bordered by dark brown and yellow] "albicillalis Led." (BMNH); Holotype apicalis §ิ [circular label with red border] "Type", [rectangular white label] "4-94", [rectangular white label] "Ceylon | 95-119", [rectangular white handwritten label] "Leucinodes | apicalis | type đે Hmpsn.”, transparent capsule with abdomen (BMNH); Holotype pseudoapicalis ô [red rectangular label] "Holotypus", [white rectangular label] “Anping | Formosa | H. Sauter VI.1911.”, [rectangular white

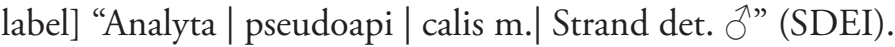

Remarks. Hyperanalyta Strand, 1918, with type species Analyta pseudoapicalis Strand, 1918 was established as a subgenus of Analyta Lederer, 1863. Later, Analyta pseudoapicalis was synonymised with Leucinodes apicalis Hampson, 1896 by Shibuya 1928. Thus, Hyperanalyta had to be regarded as a synonym of Leucinodes. Our investigation of Leucinodes apicalis, Analyta pseudoapicalis and Analyta albicillalis Lederer, 1863, the type species of Analyta Lederer, 1863, showed for all three species group taxa the presence of two frenular bristles in females (one in Leucinodes), the lack of distal discoidal stigma and L-shaped or triangular spot at central dorsum as characteristic for Leucinodes, but a homologous wing pattern common for the three taxa: forewing antemedian area brown; distal discoidal stigma a pale brown thin line; postmedian line sinuate; apical dark spot reaching outer forewing margin (white border in Leucinodes). We therefore rule out the congenerity of Leucinodes apicalis and Analyta pseudoapicalis with Leucinodes and transfer both to Analyta.

\section{Lygropia Lederer, 1863}

Type species: Asopia unicoloralis Guenée, 1854.

\section{Lygropia aureomarginalis (Gaede, 1916), comb. n. (Leucinodes)}

Type locality. Cameroon, Buea.

Material examined. Holotype $\widehat{\delta}$ [small blue label] "Gr. Kamerunberg| Buea 1.10. XI. 10 | 1000-1200 m | E. Hintz S. G.”, [large blue handwritten label with black border] "Leucinodes | aureomarginalis | 83:8a Type Gaede" (ZMHB).

Remarks. Lygropia is a polyphyletic genus containing 62 species (Nuss et al. 20032014). We provisionally transfer Lygropia aureomarginalis (Gaede, 1916), comb. n. (Leucinodes) from Cameroon to this genus, as this species, according to wing pattern elements, is congeneric, if not conspecific, to Lygropia vinanyalis Viette, 1958 from Madagascar. Lygropia aureomarginalis can be distinguished externally from species of Leucinodes by the shiny golden wing maculation and the presence of two frenulum bristles in the female. 


\section{Syllepte Hübner, 1823}

Syllepte Hübner, 1823. Type species: Syllepte incomptalis Hübner, 1823.

Syllepte hemichionalis (Mabille, 1900), comb. rev. (Sylepta [sic]). Type locality: Madagascar, baie d'Antongil

= Syllepte hemichionalis idalis Viette, 1958, comb. rev. (Syllepta [sic]). Type locality: Comoros, Mohéli.

Syllepte vagans (Tutt, 1890), comb. n. (Aphytoceros). Type locality: Great Britain, Chepstow.

= Aphytoceros longipalpis Warren, 1892 (synonymised by South, 1897). Type locality. South Africa, Transvaal.

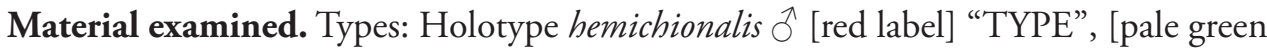
label] "MUSEUM PARIS | MADAGASCAR | BAIE D'ANTONGIL | A. MOCQUERYS 1898", [whitish handwritten label] "Sylepta | hemichionalis Mab. | Ann. Soc.Ent.Fr. | 1899 p. 745.", [whitish handwritten label] "Sylepta | hemichionalis | Mab." (MNHN); Holotype subsp. idalis đo [red label] "TYPE", [white label] "COMORES | MOHÉLI XI-1955 | A. ROBINSON”, [white handwritten label] "[underlined] Sylepta $\widehat{O} \mid$ [underlined] hemichionalis | [underlined] idalis n. subsp. | Holotype [underlined] P.Viette" (MNHN); Holotype syn. longipalpis o + [circular label with red border] "Type", [white label] "Transvaal | 91-21" (BMNH). The whereabouts of the type specimen of vagans Tutt, 1890 are not known.

Remarks. Syllepte hemichionalis and S. vagans are similar to each other in wing pattern elements, the presence of two frenular bristles in the female hindwings and features of male genitalia (see Suppl. material 2I), but not so to Leucinodes. Their wing pattern differs from Leucinodes in the following: forewing without the L-shaped or triangular spot at central dorsum of Leucinodes and without the half moon-shaped subapical patch; postmedian line broad, straight, but with long loop before dorsum, reaching to central part of forewing; dorsum with broad brown line leading from brown antemedian area to distal end of postmedian line; in the hindwing they have a comma- or V-shaped distal discoidal sigma, light brown with dark brown border. This homologous wing pattern is also found in Syllepte chalybifascia Hampson, 1896 from India and S. dottoalis Schaus, 1927 from the Philippines, and we consider them congeneric with each other as well as with $S$. hemichionalis and $S$. vagans. The genus Syllepte comprises 193 species (Nuss et al. 2003-2014), is probably polyphyletic and in need for taxonomic revision.

\section{Deanolis Snellen, 1899}

Type species: Deanolis sublimbalis Snellen, 1899 


\section{Deanolis iriocapna (Meyrick, 1938), comb. n. (Sceliodes)}

Type locality. Indonesia, Yogyakarta

Material examined. Holotype $\widehat{\delta}$ [circular label with red circle] "Holo- | type", [white label] "südl. M.-Java | Djokjakarta | H.Overbeck", [white label] "M600", [white label] "Sceliodes | iriocapna Meyr. | det. E. Meyrick.", [white label] "Sceliodes | iriocapna | 1/1 | Meyrick | E.Meyrick det. | in Meyrick Coll.", [white label] "Meyrick Coll. | B.M. 1938-290.” (BMNH).

Remarks. The wing pattern of iriocapna Meyrick, 1938 exhibits none of the features found in Leucinodes. Instead, the fore wings are pale yellow, with a yellowish costa, a dark spot in both outer edges of the cell, and a reddish undulating margin along the termen. The hind wings are of the same pale yellow ground colour, and the anterior half of the termen exhibits a similar margin as found in the fore wings. This wing pattern is common to the genus Deanolis Snellen, 1899, where this species is correctly placed (pers. comm. James E. Hayden).

\section{Identification key for African Leucinodes species based on male genitalia:}

1 Transtilla arms each with a dorsad spine ............ Leucinodes ethiopica sp. $\mathbf{n}$.

1* Genitalia without these structures .............................................................. 2

2 Sacculus without distal process; posterior phallus apodeme with finger-like process .................................................................................................. 3

2* Distal process of sacculus present; posterior phallus apodeme without fingerlike process ............................................................................................... 4

3 Fibula broad, strongly sclerotized, emerging just ventral of costa; sacculus more than half the length of valva; saccus very elongated, tip pointed; dorsal posterior phallus apodeme with slim, finger-like, well sclerotized process......

L. laisalis (Walker, 1859), comb. $n$.

$3^{*} \quad$ Fibula small, strongly sclerotized, emerging near ventral valva edge; sacculus less than half the length of valva; saccus elongated, tip not pointed; ventral posterior phallus apodeme with slim, posterioventrally protruding, well sclerotized process

L. malawiensis sp. $\mathbf{n}$.

4 Distal sacculus process projecting towards valva apex, straight or apically hooked, sometimes branching, apex dentate; juxta subulate; posterior phallus apodeme with oval saw blade-shaped sclerotization. 5

$4^{*} \quad$ Distal sacculus process tooth- or hook-like; juxta much broader; posterior phallus apodeme without oval saw blade-shaped sclerotization ....................6

5 Valva apex rounded; ventrad fibula stout, with broad base, straight or slightly curved; distal sacculus process hook-shaped, not branching, spanning $\leq$ half the distance fibula base-valva apex

L. rimavallis sp. $\mathrm{n}$.

5* Valva apex pointed; ventrad fibula slender, with narrower base, curved; distal sacculus process straight or hook-shaped, sometimes branching, spanning > half the distance fibula base-valva apex..... 
6 Dorsad fibula conical and smaller than distal sacculus process, which is large, hook-like and arching above fibula

L. kenyensis sp. $\mathrm{n}$.

$6^{*} \quad$ Dorsad fibula and fibula-like sacculus process being roughly of same shape and size and running parallel or crossing each other.

$7 \quad$ Fibula and fibula-like sacculus process large, spanning almost the entire valva transversally; ventral valva edge not straight but with arch dorsal of fibula and fibula-like process; posterior phallus apodeme ventrally with oval sclerite .....

L. pseudorbonalis sp. $\mathbf{n}$.

7* Fibula and fibula-like sacculus process small, barely reaching the valva centre; ventral valva edge more or less straight; posterior phallus apodeme without oval sclerite

L. ugandensis sp. $\mathrm{n}$.

\section{DNA Barcoding}

The Neighbor Joining (NJ) analysis based on uncorrected p-distances (Fig. 47) groups taxa which are excluded from Leucinodes in this study outside of the Leucinodes + Neoleucinodes group. Deanolis iriocapna, Leucinodes ethiopica and L. ugandensis have not been barcoded and are therefore not included in the NJ tree. The Leucinodes + Neoleucinodes group forms a polytomy comprising Neoleucinodes, L. malawiensis, L. laisalis and a group containing the remaining Leucinodes species. Within this last group, 11 barcode clusters are revealed.

Leucinodes laisalis clusters in two Barcode groups: One group containing all specimens imported with fruits from Kenya, Ghana and Nigeria, and a second group comprising a single South African specimen. This single specimen shows high uncorr-p distances of $2.4-2.8 \%$ to the other $L$. laisalis specimens.

L. orbonalis clusters in two groups, separated by $1.1-1.8 \%$ uncorr-p distance. Within-subcluster distances are $0-0.5 \%$ for the smaller and $0-0.9 \%$ for the larger of the two subclusters.

A polytomous cluster comprising $L$. rimavallis, L. kenyensis and two undescribed 'Barcode species' (Leucinodes spp.) are sister to (L. africensis + L. pseudorbonalis).

Barcode sharing among different Leucinodes morphospecies is not observed.

Table I. Uncorrected p-distances for the DNA-barcoded species of Leucinodes. Values in bold denote intraspecific distances, plain values represent interspecific distances.

\begin{tabular}{c|c|c|c|c|c|c|c}
\hline & orbonalis & africensis & rimavallis & $\begin{array}{c}\text { pseudorbo- } \\
\text { nalis }\end{array}$ & kenyensis & $\begin{array}{c}\text { mala- } \\
\text { wiensis }\end{array}$ & laisalis \\
\hline orbonalis $(\mathbf{n}=\mathbf{3 1})$ & $\mathbf{0 - 1 . 8} \%$ & & & & & & \\
\hline africensis $(\mathbf{n}=\mathbf{2 9})$ & $5.5-7.2 \%$ & $\mathbf{0 - 1 . 5 \%}$ & & & & & \\
\hline rimavallis $(\mathbf{n}=\mathbf{2})$ & $4.2-5.7 \%$ & $3.8-5.7 \%$ & $\mathbf{0 . 4} \%$ & & & & \\
\hline pseudorbonalis $(\mathbf{n}=\mathbf{1})$ & $6.4-7.0 \%$ & $5.4-6.2 \%$ & $3.3-5.2 \%$ & n.a. & & & \\
\hline kenyensis $(\mathbf{n}=\mathbf{4})$ & $5.3-6.0 \%$ & $5.4-6.2 \%$ & $2.2-2.4 \%$ & $5.2 \%$ & $\mathbf{0} \%$ & & \\
\hline malawiensis $(\mathbf{n}=\mathbf{1})$ & $9.6-10.7 \%$ & $11.4-12.1 \%$ & $10.0-10.8 \%$ & $11.7 \%$ & $11.2 \%$ & n.a. & \\
\hline laisalis $(\mathbf{n}=\mathbf{2 2})$ & $7.3-8.7 \%$ & $9.4-10.8 \%$ & $7.8-8.9 \%$ & $9.9-10.4 \%$ & $9.4-9.8 \%$ & $9.3-9.9 \%$ & $\mathbf{0 - 2 . 8 \%}$ \\
\hline
\end{tabular}




\section{Discussion}

The investigation of the Leucinodes species from sub-Saharan Africa reveals a new picture on the taxonomy of the Solanaceae fruit feeders. Instead of one widely distributed species in Asia and Africa, there is an endemic species complex in Africa and L. orbonalis is restricted to Asia, corroborating the statement by Hayden et al. (2013). Among the African species, $L$. africensis and L. laisalis are widely distributed on the continent, whereas $L$. ethiopica, L. ugandensis, L. rimavallis and L. kenyensis seem to have a rather restricted range. $L$. malawiensis is only known from one specimen from Malawi. These data may indicate different, though partly overlapping patterns of distribution as seen in Fig. 48, but this is still an incomplete dataset, resulting in fragmentary distribution patterns for $L$. pseudorbonalis and $L$. rimavallis. The possibility of transport by man also has to be taken into consideration.

Food plant data are only available for $L$. africensis, L. laisalis, $L$. pseudorbonalis, $L$. rimavallis and $L$. kenyensis (Table 2 ). While $L$. laisalis is known to feed on a variety of cultivated and non-cultivated Solanaceae, the other four species are known from cultivated Solanaceae only. This may rather refer to a bias of investigation, which so far has concentrated on fruits of economic importance. In nature, the Leucinodes species may have different host plants to which they were originally adapted. Those wild hosts may also have certain areas of origin. Such a scenario has to be expected, considering the fact that several species of Leucinodes have evolved in Africa. Some of these species might be restricted to their wild host plants and unable to switch to other, cultivated Solanaceae species. In contrast, species able to adapt to cultivated Solanaceae might be transported with fruits in trade, resulting in a larger range within Africa.

After movement of larvae with fruits in African trade, they may be more frequently intercepted by trade with those fruits into other continents. Most imports of Leucinodes specimens from Africa into Europe refer to Leucinodes africensis, which has been frequently imported with fruits during the last 50 years. In contrast, L. laisalis has been much less frequently recorded, and $L$. pseudorbonalis as well as $L$. rimavallis only very recently in fruit imports from Uganda. Since our investigations show that $L$. orbonalis does not occur in Africa, interceptions of Leucinodes from Africa into other continents

Table 2. Food plant records of African Leucinodes species. Cultivated plants are given in bold.

\begin{tabular}{c|c|c|c|c|c}
\hline & L. africensis & L. kenyensis & L. laisalis & L.pseudorbonalis & L. rimavallis \\
\hline Capsicum annuum & & & $\mathrm{x}$ & & \\
\hline Solanum anguivi & & & $\mathrm{x}$ & & \\
\hline Solanum aethiopicum & $\mathrm{x}$ & & & $\mathrm{x}$ & \\
\hline Solanum incanum & & & $\mathrm{x}$ & & \\
\hline Solanum linnaeanum & & & $\mathrm{x}$ & & \\
\hline Solanum lycopersicon & $\mathrm{x}$ & & $\mathrm{x}$ & & \\
\hline Solanum macrocarpon & & & $\mathrm{x}$ & & \\
\hline Solanum melongena & $\mathrm{x}$ & & $\mathrm{x}$ & $\mathrm{x}$ & $\mathrm{x}$ \\
\hline Withania somnifera & & $\mathrm{x}$ & & & $\mathrm{x}$ \\
\hline
\end{tabular}




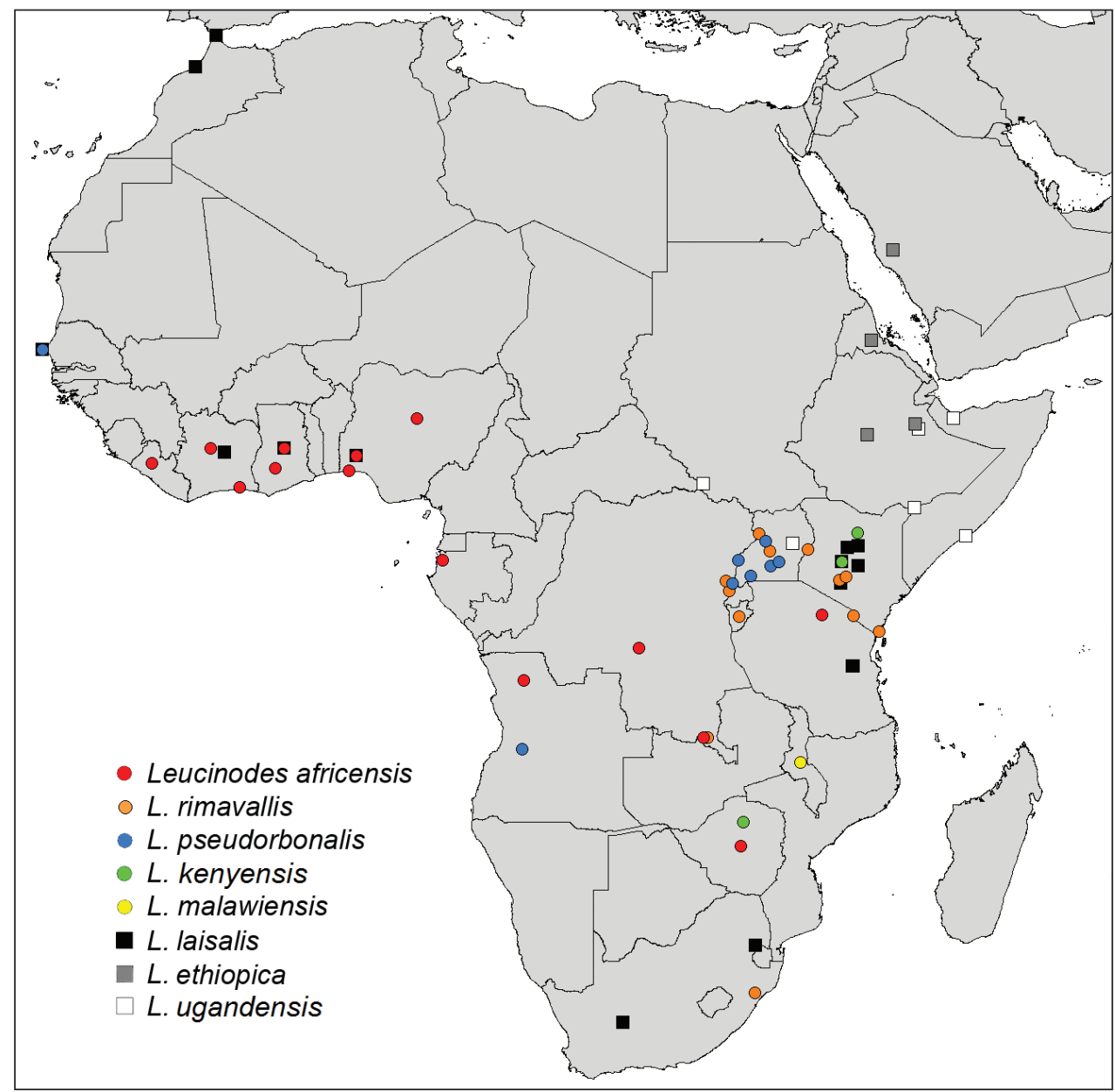

Figure 48. Distribution map of African Leucinodes species.

will need to be re-investigated for their species identity and will likely require, at least in parts, revisions of the quarantine regulations. Furthermore, if Leucinodes species are transported in trade, it has to be considered that species of Leucinodes and related South American genera, e.g. Euleucinodes Capps, 1948, Neoleucinodes and Proleucinodes, might also become introduced from one to another of the southern continents.

Analysis of the COI gene of the Leucinodes species demonstrated that interspecific differences allow the use of the marker as a DNA barcode for species identification. However, for L. kenyensis and "Leucinodes spp.", we found little morphological differences but two distinct barcode species within Leucinodes spp. Moreover, we observed high intraspecific divergence in Leucinodes laisalis with one specimen from South Africa exhibiting a COI distance of $2.8 \%$.

Outside Africa, the taxonomy and phylogeny of Leucinodes requires further research. The characteristic forewing pattern elements of the Old World Leucinodes is 
also found in the New World genera Euleucinodes, Neoleucinodes and Proleucinodes, all described by Capps (1948). In male genitalia, Leucinodes is distinguished from these three genera by the absence of cornuti in the phallus, from Euleucinodes and Proleucinodes also by the presence of a fibula, and further from Euleucinodes by the dorsal location of the uncus spines. In female genitalia, Leucinodes is distinguished from Proleucinodes by the presence of lateral antrum pockets (condition unknown in Euleucinodes), but cannot be clearly distinguished from Neoleucinodes, in which antrum pockets can be absent (e.g., $N$. elegantalis (Guenée, 1854)) or present (Neoleucinodes prophetica (Dyar, 1914), N. torvis Capps, 1948), and pocket sclerites can be absent (e.g., $N$. elegantalis) or present ( $N$. imperialis (Guenée, 1854), N. torvis). Whether these differences refer to a typological classification or justify the maintenance of the current generic classification needs to be investigated by phylogenetic analysis.

For Austral-Asia, there remain twelve nominal Leucinodes species (Nuss et al. 2003-2014). Other than L. orbonalis, at least some of these species are certainly misplaced in Leucinodes, e.g. Leucinodes labefactalis Swinhoe, 1904 from Borneo and Leucinodes perlucidalis Caradja, 1933 from China. Therefore, the Asian Leucinodes are in need of taxonomic revision. This also points to the question whether all Leucinodes samples intercepted from Asian exports refer to L. orbonalis, or whether there are several Leucinodes species of economic importance in Asia as well (Hayden et al. 2013, Chang et al. 2014, Gilligan and Passoa 2014).

Our work contributes to the identification of African Leucinodes species, based on adult characters and on DNA Barcodes, by which also the immature stages can be efficiently distinguished. This may help to systematically survey the continent for distribution of species, in order to discover their wild host plants and their movements in trade. At this stage of knowledge it wouldn't be a surprise to discover additional, still unknown species. The results of our completely revised taxonomy of African Leucinodes suggests that a revision of the EPPO A1 List of pests recommended for regulation as quarantine pests (EPPO 2013) will be necessary. During the period from 2004 to 2007, 121 interceptions of Solanum fruits infested by Leucinodes were recorded by several EPPO member countries. The majority ( 94 consignments) originated from Thailand, Ghana accounted for 18 infested consignments (EPPO 2008). L. orbonalis is also ranked as quarantine species important for the USA, but specimens intercepted from Africa cannot be L. orbonalis, as stated by Hayden et al. (2013) and Gilligan and Passoa (2014) and as shown by our results. The USA has recorded 1745 interceptions from Ghana to the USA between 1985 and 2004 (Boateng et al. 2005).

\section{Conclusion}

A careful revision of Leucinodes in sub-Saharan Africa resulted in the new synonymy of the genus Sceliodes syn. n., the revised synonymy of Hyperanalyta with Analyta, the transfer of four species to Leucinodes, the description of seven new Leucinodes species, the new synonymy of one species, the omission of the type species L. orbonalis from the 
African list and the generic transfer of five species found to be misplaced in Leucinodes. Of the eight species recognized from Africa now, at least four are frequently intercepted among imports of solanaceous fruits at European ports of entry. We provide the DNA Barcode for these four and two additional African Leucinodes species, allowing the identification of all life stages of these species.

Our work shows that typological concepts of taxonomy based on superficial similarity were still the state of the art in the genus Leucinodes. The discovery of a complex of highly similar species demonstrates that traditional morphological methods and DNA Barcoding are helpful tools to detect species diversity and to improve their classification based on sound arguments.

Similar revisionary work remains to be done for Austral-Asian Leucinodes. A phylogenetic study including Leucinodes and the New World Euleucinodes, Neoleucinodes and Proleucinodes is needed in order to test the monophyly of these genera (Hayden and Mally, in prep.).

\section{Acknowledgements}

For the loan of material and communication to the material deposited at their institutions or private collections, we thank Leif Aarvik (NHMO Oslo, Norway), Robert Copeland (ICIPE Nairobi, Kenya), Jurate De Prins (formerly at RMCA Tervuren, Belgium), James Hogan and Molly Carter (Oxford Museum, Great Britain), Timm Karisch (Dessau, Germany), Christian Kutzscher (SDEI Müncheberg, Germany), Scott Miller (USNM Washington, D.C., USA), Joël Minet, Patrice Leraut and Jerome Barbut (MNHN Paris, France), Wolfram Mey and Konrad Ebert (ZMHB Berlin, Germany), Marja van der Straten (NPPO Wageningen, the Netherlands) as well as Kevin Tuck, Thomas Simonsen and the NHM staff (BMNH London, Great Britain). We thank Martin Corley (Faringdon, Great Britain), Christopher Grinter (Denver Museum of Natural History, Denver, USA), Ole Karsholt (ZMUC Copenhagen, Denmark) for their support with literature. James E. Hayden (Florida State Collection of Arthropods, Gainesville, USA) informed us on the correct generic placement of iriocapna Meyrick, 1938. Manuela Bartel (SMTD Dresden, Germany) accomplished a part of the molecular work in the DNA lab of the SMTD. Francesca Vegliante (SMTD Dresden, Germany) gave manuscript advice on the immature stages. Heiko Stuckas gave advice on the molecular analysis of Barcode data.

Field work in Kenya by MN was greatly supported by Fritz Schulthess, Benjamin Muli and Gerphas Okuku (ICIPE Nairobi, Kenya). Research by MN in Angola was made possible by a collaboration with Christoph Neinhuis and Thea Lautenschläger (Technische Universität Dresden, Germany) as well as by the Universidade Kimpa Vita, Uíge, Angola, supported by a Grant of the German Academic Exchange Service (DAAD).

Thea Lautenschläger (Technische Universität Dresden, Germany) and Gerard van der Weerden (Radboud University Nijmegen, the Netherlands) identified the Angolan host plants of $L$. africensis. 
This study was supported by a SYNTHESYS grant for the visit of RM at the BMNH London. Fera acknowledges the support of Defra Plant Health Policy. Material reared at Fera was under the authority of Plant Health Licence number 33173/220099-2 and its predecessors.

\section{References}

Agassiz DJL (1983) Microlepidoptera - a review of the year 1982. The Entomologist's Record and Journal of Variation 95: 187-195.

Altschul SF, Gish W, Miller W, Myers EW, Lipman DJ (1990) Basic Local Alignment Search Tool. Journal of Molecular Biology 215 (3): 403-410. doi: 10.1016/S00222836(05)80360-2

Boateng BA, Braimah H, Glover-Amengor M, Osei-Sarfo A, Woode R, Robertson S, Takeuchi Y (2005) Importation of Eggplant, Solanum melongena from Ghana into the United States. Council of Scientific and Industrial Research Ghana, CSOR-FRI/RE/ BBA/2005/014, 1-34.

Boonham N, Smith P, Walsh K, Tame J, Morris J, Spence N, Bennison J, Barker I (2002) The detection of Tomato spotted wilt virus (TSWV) in individual thrips using real time fluorescent RT-PCR (TaqMan). Journal of Virological Methods 101: 37-48. doi: 10.1016/ S0166-0934(01)00418-9

CABI (2012a) Crop Protection Compendium datasheet on Leucinodes orbonalis. http://www. cabi.org $/ \mathrm{cpc} /$ ?compid=1\&dsid=30498\&loadmodule=datasheet $\&$ page $=868 \&$ site $=161$ [accessed 20 August 2012]

CABI (2012b) Daraba laisalis. http://www.cabi.org/isc/datasheet/17924

Capps HW (1948) Status of the pyraustid moths of the genus Leucinodes in the New World, with descriptions of new genera and species. Proceedings of the United States National Museum 98(3223): 69-83. doi: 10.5479/si.00963801.98-3223.69

Chang JC, Ponnath DW, Ramasamy S (2014) Phylogeographical structure in mitochondrial DNA of eggplant fruit and shoot borer, Leucinodes orbonalis Guenée (Lepidoptera: Crambidae) in South and Southeast Asia. Mitochondrial DNA 2014: 1-7. doi: $10.3109 / 19401736.2014 .880890$

Cornish-Bowden A (1985) Nomenclature for incompletely specified bases in nucleic acid sequences: recommendations 1984. Nucleic Acids Research 13: 3021-3030. doi: 10.1093/ nar/13.9.3021

COSAVE (2006) Listado de las principales plagas reglamentadas para la región del COSAVE. http://www.cosave.org/pagina/listado-de-las-principales-plagas-reglamentadas-para-laregion-del-cosave [accessed 03 January 2013]

Davis JJ (1964) The egg fruit caterpillar. Queensland Agricultural Journal 90: 76-78.

Doubleday H (1843) Lepidoptera. In: List of the annulose animals hitherto recorded as found in New Zealand, with the descriptions of some new species. In: Dieffenbach E (Ed.) Travels in New Zealand: with contributions to the geography, geology, botany and natural history of the country, vol. 2. John Murray, London, 283-289. 
Dugdale JS (1988) Lepidoptera - annotated catalogue, and keys to family-group taxa. Fauna of New Zealand, Wellington 14: 1-262.

Duodu YA (1986) Field evaluation of eggplant cultivars to infestation by the shoot and fruit borer, Leucinodes orbonalis (Lepidoptera, Pyralidae) in Ghana. Tropical Pest Management 32: 347-349. doi: 10.1080/09670878609371092

Dyar HG (1914) Report on the Lepidoptera of the Smithsonian Biological Survey of the Panama Canal Zone. Proceedings of the United States National Museum 47 (2050): 139-350. doi: 10.5479/si.00963801.47-2050.139

EPPO (2008) Leucinodes orbonalis is regularly intercepted in the EPPO region: addition to the EPPO Alert List. EPPO Reporting Service 2008 (1): 8-9. http://archives.eppo.int/EPPOReporting/2008/Rse-0801.pdf (accessed 09 April 2014)

EPPO (2012) New additions to the EPPO A1 and A2 Lists. EPPO Reporting Service 2012 (9): 2. http://archives.eppo.int/EPPOReporting/2012/Rse-1209.pdf [accessed 09 April 2014]

EPPO (2013) EPPO A1 List of pests recommended for regulation as quarantine pests. http:// www.eppo.int/QUARANTINE/listA1.htm (accessed 09 April 2014)

Folmer O, Black M, Hoeh W, Lutz R, Vrijenhoek R (1994) DNA primers for amplification of mitochondrial cytochrome c oxidase subunit I from diverse metazoan invertebrates. Molecular Marine Biology and Biotechnology 3 (5): 294-299.

Frempong E (1979) The nature of damage to egg plant (Solanum melongena L.) in Ghana by two important pests, Leucinodes orbonalis Gn. and Euzophera villora (Fldr.) (Lepidoptera Pyralidae). Bulletin de l'Institut Fondamental d'Afrique 41 (2): 408-416.

Frempong E, Buahin GKA (1977) Studies on the insect pests of egg plant, Solanum melongena L., in Ghana. Bulletin de l'Institut Fondamental d'Afrique Noire, Serie A 39: 627-641.

Gaede M (1916) Pyralididae, gesammelt von Herrn E. Hintz 1910 in Kamerun (Microlepidoptera). Stettiner Entomologische Zeitung 77: 127-138.

Gaede M (1917) Neue Lepidopteren des Berliner Zoologischen Museums. I. Aethiopische Pyralididen. Mitteilungen aus dem Zoologischen Museum in Berlin 8 (3): 387-401.

Gilligan TM, Passoa SC (2014) Fact sheet Leucinodes orbonalis Guenée. LepIntercept - An identification resource for intercepted Lepidoptera larvae. http://idtools.org/id/leps/ lepintercept/pdfs/orbonalis.pdf

Guenée MA (1854) Deltoides et Pyralites. In: Boisduval JBAD de, Guenée MA (Eds) Histoire Naturelle des Insectes. Species Général des Lépidoptères 8 8. Roret, Paris, 1-448.

Hajibabaei M, Janzen DH, Burns JM, Hallwachs W, Hebert PDN (2006) DNA barcodes distinguish species of tropical Lepidoptera. Proceedings of the National Academy of Sciences 103: 968-971. doi: 10.1073/pnas.0510466103

Hampson GF (1896) Moths. The Fauna of British India, including Ceylon and Burma, London 4: i-xxviii, 1-594.

Hampson GF (1899) A revision of the moths of the subfamily Pyraustinae and family Pyralidae. Part II. Proceedings of the General Meetings for Scientific Business of the Zoological Society of London 1899 (1): 172-291.

Hayden JE, Lee S, Passoa SC, Young J, Landry J-F, Nazari V, Mally R, Somma LA, Ahlmark KM (2013) Digital Identification of Microlepidoptera on Solanaceae. USDA-APHIS- 
PPQ Identification Technology Program (ITP). Fort Collins, CO. http://idtools.org/id/ leps/micro/ [accessed 07 February 2014]

Higgott J (2009) Leucinodes orbonalis Guenée, 1854 (Lepidoptera: Pyralidae), a species not previously recorded in the wild in Great Britain. Entomologist's Gazette 60 (1): 25-27.

Hijmans RJ, Guarino L, Bussink C, Mathur P, Cruz M, Barrentes I, Rojas I (2004) DIVAGIS. Version 7.2.3. A geographic information system for the analysis of species distribution data. http://www.diva-gis.org/

Hinton H (1946) On the homology and nomenclature of the setae of lepidopterous larvae, with some notes on the phylogeny of the Lepidoptera. Transactions of the Royal Entomological Society of London 97: 1-37. doi: 10.1111/j.1365-2311.1946.tb00372.x

Horna D, Smale M, Falck-Zepeda J (2007) Assessing the Potential Economic Impact of Genetically Modified Crops in Ghana: Insect-Resistant Garden Egg. International Food Policy Research Institute, Brief no. 4.

Hübner J (1796-1833 [imprint “1796”]) Sammlung europäischer Schmetterlinge. 6. Horde. Die Zünsler; nach der Natur geordnet, beschrieben und vorgestellt (continued by C. Geyer). Augsburg, [i]-[iv], [i-ii], [i-ii], 1-30, [i-ii], [i-ii], pls. 1-32.

Hübner J (1819-1823 [imprint “1823”]) Zuträge zur Sammlung exotischer Schmettlinge [sic], bestehend in Bekundigung einzelner Fliegmuster neuer oder rarer nichteuropäischer Gattungen. Augsburg, [1]-[3]-4-6-[7]-8-3-33]-[40], pl. [36]-[69].

Huertas Dionisio M (2000) Immature states of Lepidoptera (XIII). Three species of tropical origin of the subfamily Pyraustinae Meyrick, 1890: (Lepidoptera: Pyraloidea, Crambidae). Shilap. Revista de Lepidopterologia 28(111): 321-334.

Kemal M, Koçak AÖ (2007) Synonymous checklist of the South African Lepidoptera. http:// www.metafro.be/Members/Cesa/Cesapublafri2.pdf [accessed 10 August 2012]

Knapp S, Vorontsova MS, Prohens J (2013) Wild relatives of the eggplant (Solanum melongena L.: Solanaceae): New understanding of species names in a complex group. PLoS ONE 8 (2): e57039. doi: 10.1371/journal.pone.0057039

Knölke S, Erlacher S, Hausmann A, Miller MA, Segerer AH (2005) A procedure for combined genitalia dissection and DNA extraction in Lepidoptera. Insect Systematics \& Evolution 35: 401-409. doi: 10.1163/187631204788912463

Kopij G (2005) Lepidoptera fauna of Lesotho. Acta zoologica cracoviensia 49B: 137-180.

Lederer J (1863) Beitrag zur Kenntniss der Pyralidinen. Wiener Entomologische Monatschrift 7(8, 10-12): 243-280, 331-504, pls 2-18.

Mabille P (1900) Lepidoptera nova malgassica et africana. Annales de la Société Entomologique de France 68: 723-753.

Martin NA (2010) Poroporo Fruit Borer - Sceliodes cordalis. New Zealand Arthropod Collection Factsheet Series, ISSN 1179-643X. http://nzacfactsheets.landcareresearch.co.nz/ factsheet/OrganismProfile/Poroporo_fruit_borer_-_Sceliodes_cordalis.html

Meyrick E (1938) New Javanese Lepidoptera. Deutsche entomologische Zeitschrift Iris 52(2): 73-88. Moore F (1884-1887 [imprint “1885”]) The Lepidoptera of Ceylon. L. Reeve, London, xvi + 578 pp., pls 144-214.

Müller K, Müller J, Neinhuis C, Quandt D (2008) PhyDE - Phylogenetic data editor, Version 0.9971. http://www.phyde.de/ 
Nuss M, Landry B, Mally R, Vegliante F, Tränkner A, Bauer F, Hayden JE, Segerer A, Schouten R, Li H, Trofimova T, Solis MA, De Prins J, Speidel W (2003-2014) Global Information System on Pyraloidea. http://www.pyraloidea.org

Nyst RH (2004) Quand l'Afrique fait du tourisme sous la forme de Sceliodes laisalis (Lepidoptera: Crambidae). Phegea 32 (4): 147-148.

Ogunwolu EO (1978) Sceliodes laisalis (Pyralidae): Description of the mature larva and note on its feeding habit. Journal of the Lepidopterists' Society 32: 175-177.

Pagenstecher AAF (1900) Die Lepidopterenfauna des Bismarck-Archipels. Mit Berücksichtigung der thiergeographischen und biologischen Verhaeltnisse. Zweiter Theil: Die Nachtfalter. Zoologica 29: 1-268, errata, pls 1-2.

Pandey G (2010) India divided over plans for GM aubergine. BBC News. http://news.bbc. co.uk/2/hi/south_asia/8503825.stm

Poulton EB (1916) On a collection of moths made in Somaliland by Mr. W. Feather with descriptions of new species by Sir G. F. Hampson, L. B. Prout, J. H. Durrant and Dr. Karl Jordan. Proceedings of the Zoological Society of London 86: 91-182.

Robineau-Desvoidy AJD (1863) Histoire naturelle des diptères des environs de Paris 1: i-xvi, $1-1143$.

Robinson GS (1976) The preparation of slides of Lepidoptera genitalia with special reference to the Microlepidoptera. Entomologist's Gazette 27: 127-132.

Saitou N, Nei M (1987) The neighbor joining method: a new method for reconstructing phylogenetic trees. Molecular Biology and Evolution 4 (4): 406-425.

Shaffer M, Nielsen ES, Horak M (1996) Pyraloidea. In: Nielsen ES, Edwards ED, Rangsi TV (Eds) Checklist of the Lepidoptera of Australia. In: Nielsen ES. Monographs on Australian Lepidoptera 4 4. CSIRO Division of Entomology, Canberra, 164-199.

Shibuya J (1928) The systematic study on the Formosan Pyralidae. Journal of the Faculty of Agriculture, Hokkaido Imperial University 22(1): 1-300, pls 1-9.

Snellen PCT (1880) Nieuwe Pyraliden op het Eiland Celebes gevonden door Mr. M. C. Piepers. Tijdschrift voor Entomologie 23: 198-250.

Snellen PCT (1899) Nieuwe Aanteekeningen over Pyraliden. Tijdschrift voor Entomologie 42 (1-2): 58-95, pls 3-4.

Solis MA (1999) Key to selected Pyraloidea (Lepidoptera) larvae intercepted at U.S. ports of entry: revision of Pyraloidea in "Keys to some frequently intercepted lepidopterous larvae" by D. M. Weisman 1986. Proceedings of the Entomological Society of Washington 101: 645-686.

Solis MA (2006) Key to selected Pyraloidea (Lepidoptera) larvae intercepted at U.S. ports of entry: revision of Pyraloidea in "Keys to some frequently intercepted lepidopterous larvae" by D. M. Weisman 1986 (updated 2006). www.ars.usda.gov/SP2UserFiles/Place/12754100/ PyraloideaKey.pdf [accessed 11 December 2012]

Sood J (2012) Whose germplasm is it? Down To Earth (Oct 1-15, 2012). http://www.downtoearth.org.in/content/whose-germplasm-it

South R (1897) Leuctinodes vagans. The Entomologist, London 30: 126.

Speidel W (1996) Pyraloidea [part]. In: Karsholt O, Razowski J. The Lepidoptera of Europe. A distributional checklist. Apollo Books, Stenstrup, 166-183, 187-196, 319-327. 
Srivathsan A, Meier R (2011) On the inappropriate use of Kimura-2-parameter (K2P) divergences in the DNA-barcoding literature. Cladistics 27: 1-5.

Strand E (1918) H. Sauter's Formosa-Ausbeute: Pyralididae, Subfam. Pyraustinae. Deutsche entomologische Zeitschrift Iris, Dresden 32(1/2): 33-91.

Tamura K, Dudley J, Nei M, Kumar S (2007) MEGA4: Molecular Evolutionary Genetics Analysis (MEGA) software version 4.0. Molecular Biology and Evolution 24: 1596-1599. doi: $10.1093 / \mathrm{molbev} / \mathrm{msm} 092$

Tamura K, Stecher G, Peterson D, Filipski A, Kumar S (2013) MEGA6: Molecular Evolutionary Genetics Analysis version 6.0. Molecular Biology and Evolution 30: 2725-2729. doi: $10.1093 / \mathrm{molbev} / \mathrm{mst} 197$

Tutt JW (1890) Aphytoceros vagans (Mihi), a species new to science. The Entomologist's Record and Journal of Variation 1(8): 203.

van der Gaag DJ, Stigter H, Lammers JW, van der Straten M (2005) Pest risk analysis Leucinodes orbonalis (Guenée). Plant Protection Service, The Netherlands, 1-43.

van der Straten M (2005) Leucinodes orbonalis (Guenée) (Lepidoptera, Crambidae): tropical treat or tropical threat? Poster presentatin, XIV. European Congress of Lepidopterology, Rome 2005.

Viette P (1958) Pyrales de la region Malgache nouvelles ou peu connues (Lepidoptera). Mémoires de l'Institut Scientifique de Madagascar, Sér. Entom., Tananarive 9: 119-156.

Viette P (1981) Nouvelles pyrales de Madagascar (Lepidoptera). Nouvelle Revue d'Entomologie 11(3): 315-319.

Wahlberg N, Wheat CW (2008) Genomic outposts serve the phylogenomic pioneers: Designing novel nuclear markers for genomic DNA extractions of Lepidoptera. Systematic Biology 57(2): 231-242. doi: 10.1080/10635150802033006

Walker F (1859) Pyralides. List of the Specimens of Lepidopterous Insects in the Collection of the British Museum 17: 255-508.

Walker F (1866) Supplement 4. List of the Specimens of Lepidopterous Insects in the Collection of the British Museum, London 34: 1121-1533.

Walker F (1866) Supplement 5. List of the Specimens of Lepidopterous Insects in the Collection of the British Museum, London 35: 1535-2040.

Warren W (1892) Descriptions of new genera and species of Pyralidae contained in the British Museum collection. Annals and Magazine of Natural History, including Zoology, Botany and Geology, London (ser. 6) 9: 172-179, 294-302, 389-397, 429-442.

Whittle K, Ferguson DC (1987) Pests not known to occur in the United States or of limited distribution No. 85: eggplant fruit borer. US Department of Agriculture, Animal and Plant Health Inspection Service 85: 1-9. 


\section{Supplementary material I}

Overview of specimens intercepted in Great Britain by the Food and Environment Research Agency (Fera).

Authors: Richard Mally, Anastasia Korycinska, David J. L. Agassiz, Jayne Hall, Jennifer Hodgetts, Matthias Nuss

Data type: sample list.

Copyright notice: This dataset is made available under the Open Database License (http://opendatacommons.org/licenses/odbl/1.0/). The Open Database License $(\mathrm{ODbL})$ is a license agreement intended to allow users to freely share, modify, and use this Dataset while maintaining this same freedom for others, provided that the original source and author(s) are credited.

\section{Supplementary material 2}

\section{Overview of barcoded specimens.}

Authors: Richard Mally, Anastasia Korycinska, David J. L. Agassiz, Jayne Hall, Jennifer Hodgetts, Matthias Nuss

Data type: sample list.

Copyright notice: This dataset is made available under the Open Database License (http://opendatacommons.org/licenses/odbl/1.0/). The Open Database License $(\mathrm{ODbL})$ is a license agreement intended to allow users to freely share, modify, and use this Dataset while maintaining this same freedom for others, provided that the original source and author(s) are credited. 